\title{
Research on the Technology of Plugging Gushing Water in the Vertical Shaft under Complicated Conditions
}

\author{
Chuanyang Jia $\mathbb{D}^{1,2}$ Hailong Wang, ${ }^{1,2}$ Haiquan Liu, ${ }^{3}$ Guibin Zhang, ${ }^{1,2}$ and Kaihua Sheng ${ }^{4}$ \\ ${ }^{1}$ School of Architecture, Linyi University, Linyi 276000, China \\ ${ }^{2}$ Linyi City Key Lab of Appraisement and Strengthening in Building Structures, Linyi 276000, China \\ ${ }^{3}$ Baodian Coal Mine, Yanzhou Coal Mining Company Limited, Yanzhou 273513, China \\ ${ }^{4}$ State Key Laboratory of Mining Disaster Prevention and Control Co-founded by Shandong Province and the Ministry of Science \\ and Technology, Qingdao 266590, China \\ Correspondence should be addressed to Chuanyang Jia; jackjia1988@126.com
}

Received 3 November 2020; Revised 24 November 2020; Accepted 5 December 2020; Published 14 December 2020

Academic Editor: Bin Gong

Copyright (C) 2020 Chuanyang Jia et al. This is an open access article distributed under the Creative Commons Attribution License, which permits unrestricted use, distribution, and reproduction in any medium, provided the original work is properly cited.

\begin{abstract}
The shaft is the throat of the mine construction, and it is easily disturbed by gushing water, which affects the mine construction progress. Aiming at technical problems under complex hydrogeological conditions in coal mines, such as vertical shaft lining rupture and serious gushing water, single-liquid and double-liquid cement grouting materials are invalid for multiple plugging of gushing water. Combining with geological data to analyze the conditions of the aquifers and water-blocking layer in the shaft, adopting the multifunctional digital electrical method and digital flow measuring instrument can accurately grasp the flow direction and flow velocity and further obtain the aquifer parameters of the main and auxiliary shafts. At the same time, based on the FLAC numerical simulation software, research on the stress, displacement, and plastic failure of the shaft surrounding rock under different water pressures ( 0.5 times, 1 time, and 2 times the hydrostatic pressure) and comparative analysis of the influence of the water bodies on the shaft surrounding rock are carried out. On this basis, the following are the objectives: (1) research the mechanical properties of polymer chemical material Malisan $\mathrm{N}$ and the mechanism of grouting to plugging gushing water and strengthening surrounding rock, (2) formulate the grouting drilling layout and construction technology for the topsoil and bedrock section of the main and auxiliary shafts, and (3) carry out long-term monitoring of the water inflow. The monitoring data showed that the measured water inflow was less than $0.05 \mathrm{~m}^{3} / \mathrm{h}$ after the grouting of the shaft surrounding rock, which achieved the purpose of preventing the shaft linings from rupturing, plugging the gushing water, and stabilizing the aquifer water pressure.
\end{abstract}

\section{Introduction}

Shaft engineering is one of the main projects of mine construction; the shaft construction accounts for about $5 \%$ of the mine underground engineering quantity and 40\% 50\% of the mine construction time. The shaft engineering construction speed directly affects the construction of roadway engineering, surface engineering, and electromechanical installation engineering [1-5]. Therefore, accelerating the shaft construction speed is an important part of shortening the mine construction time. At the same time, the shaft is the throat of the entire mine construction; its design and construction quality are directly related to the success or failure of the mine construction [6]. The hydrogeological conditions of many mines in our country are complex, with a large number of aquifers and rich water content. Besides, a large amount of water in the shaft during the shaft construction seriously affects the construction speed and quality of the shaft engineering [7-12]. The freezing method is used in the construction of shafts, and the construction of shaft linings mostly adopts reinforced concrete materials to form double-layer or composite sandwich structures. When the construction of the freezing section is completed, the shaft linings are affected by the melting and settlement of the frozen surrounding rock, the poor concrete quality, and the consolidation and settlement of aquifers at the bottom of the 


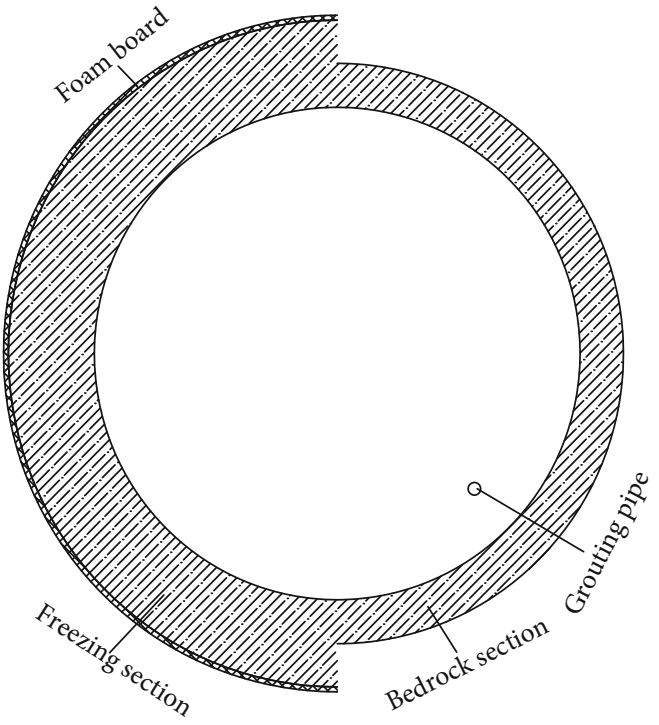

(a) Main shaft

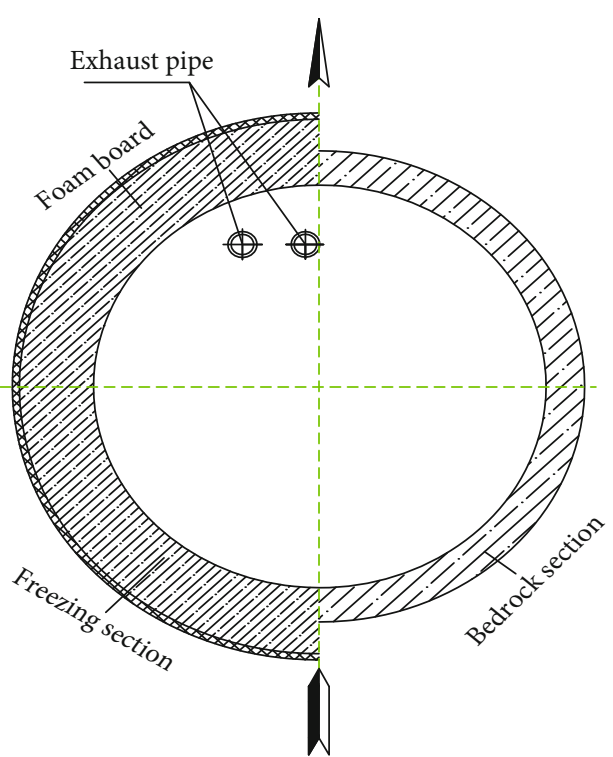

(b) Auxiliary shaft

FIGURE 1: Shaft section view.
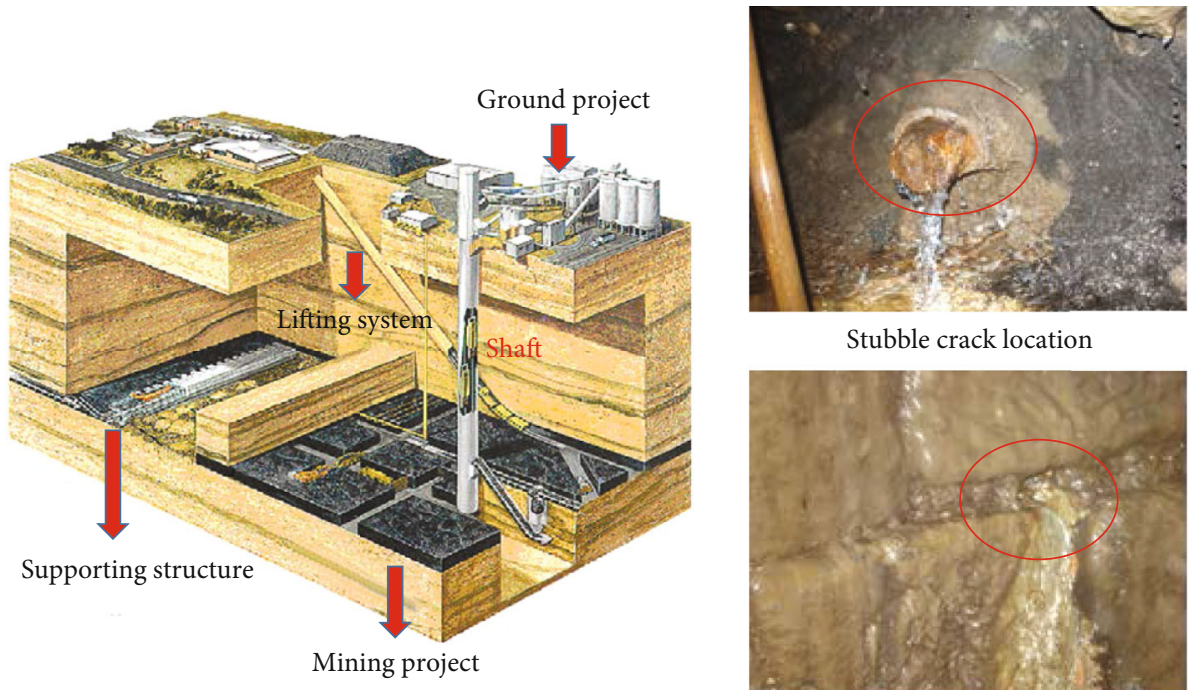

Stubble crack location

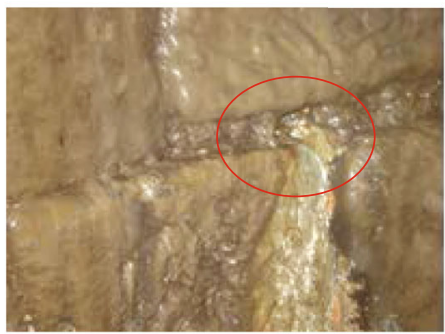

Annular crack position

Figure 2: The shaft water gush.

topsoil due to drainage; it is easy to cause shaft lining cracks and water (sand) leakage at the stubble [13-15]. The depths of the main and auxiliary shafts of the coal mine are, respectively, $390 \mathrm{~m}$ and $398 \mathrm{~m}$, the shaft diameter is $5 \mathrm{~m}$, and the topsoil thickness is $250 \mathrm{~m}$. The topsoil section of the shaft adopts short segment excavation; the excavation section height is $1.00 \mathrm{~m}$; installing the inner layer to form doublelayer shaft linings, there are annular gaps in many parts of the shaft linings; the cement slurry is filled between the shaft linings. The bedrock section of the shaft is constructed by the short section excavation and masonry mixed operation method; the height of the excavation and masonry section is $3.20 \mathrm{~m}$. The sections of the main and auxiliary shafts are shown in Figure 1. The hydrogeological conditions of the shaft are complicated, and the common method [16-18] behind the shaft lining grouting is used to plug the water outlet point at the stubble of the bedrock section, and the water plugging effect is not ideal. After grouting, the measured water inflow of the shaft reaches $6 \mathrm{~m}^{3} / \mathrm{h}$, the topsoil section is $4 \mathrm{~m}^{3} / \mathrm{h}$, and the bedrock section is $2 \mathrm{~m}^{3} / \mathrm{h}$. Especially when the temperature is lower than $-10^{\circ} \mathrm{C}$, the gushing water from the shaft linings is more obvious; the range of water inflow reaches $8 \sim 10 \mathrm{~m}^{3} / \mathrm{h}$. The water outlet points of the topsoil section are concentrated in the annular gap (shaft depth $90 \sim 110 \mathrm{~m}, 180 \sim 210 \mathrm{~m}$ ), and the water outlet points of the bedrock section are concentrated near the stubble (shaft depth $270 \sim 300 \mathrm{~m}, 320 \sim 360 \mathrm{~m}$ ). There are more water outlet points in the topsoil section than in the bedrock section, and the water inflow is relatively large. The shaft gushing water is shown in Figure 2. 


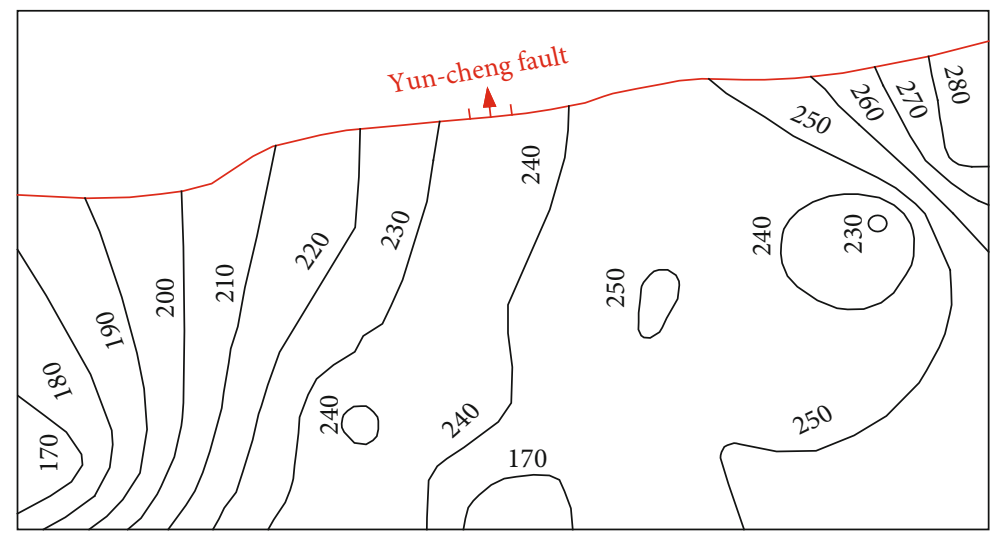

FIGURE 3: Quaternary contour map.

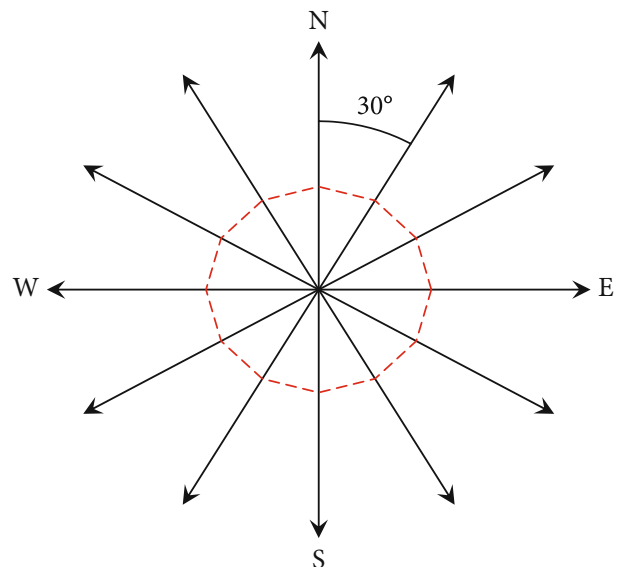

FIgURE 4: Schematic diagram of the survey line layout.

Properly handling the shaft gushing water problem is an important task during the rapid construction and operation of the vertical shaft. It is necessary to carry out the grouting between or behind the composite shaft linings in time to plug the cracks; the inner and outer shaft linings can bear the ground pressure and water pressure together to improve the overall bearing capacity of the shaft linings and further ensure the safety of the shaft and the working environment. According to the water seepage characteristics of the shaft, this paper researches the serious gushing water in the vertical shaft under complex hydrogeological conditions, and the repeated plugging effect is not obvious. A series of processes are taken, such as analyzing the gushing water mechanism [19-22], selecting grouting materials, determining the grouting plan, and developing plugging technology, so as to improve the mine production environment and realize safe production, which is of great significance.

\section{Complex Hydrological Analysis}

2.1. Geological Structure around the Shaft. The underground data reveals that there are a large number of faults, and 27 faults are exposed. The maximum fault vertical distance is
$58 \mathrm{~m}$, and the width is $0.5 \mathrm{~m}$. Most of the faults do not contain water, and only a few faults have water dripping and weak water abundance. However, from the analysis of the distribution of leaky boreholes, there are more leaking points near the fault, indicating that the rocks near the fault are relatively broken and the fractures are developed, resulting in relatively enhanced water richness on both sides of the fault.

The main shaft inspection hole is located in the YF7 fault fracture zone, and the auxiliary shaft inspection hole is located on the upper plate of the YF7 fault. The fault trend is SW and is inclined NW, the dip angle is $70^{\circ}$, and the fault drop near the shaft is $70-80 \mathrm{~m}$.

2.2. Shaft Bedrock Aquifer. In the Quaternary loose soil layer, the clayey soil with poor water conductivity and the sandy soil with good water permeability alternately exist. The hydraulic connection between the Quaternary and the shaft is strong, and the groundwater has a strong replenishment capacity for the shaft. The effluent stratum is the fractured aquifer of the Upper Jurassic Mengyin Formation sandstone, the Permian Shihezi Formation sandstone, and the Shanxi Formation sandstone, with weak water content and difficult drainage.

2.3. Shaft Barrier. The Quaternary is mainly composed of clay, sandy clay, and gravel layers, with a thickness of $251.70 \sim 253.27 \mathrm{~m}$. The stratum is thick in the east and southeast and thin in the west and northwest, as shown in Figure 3. The clay has strong swelling properties and forms a relative aquifer. In the other two inspection holes, the Upper Shihezi Formation is dominated by claystone and mudstone, which can be used as a relative aquifer, which is squeezed and dislocated, causing cracks to develop and weakening water barrier performance.

2.4. Shaft Water Gush Analysis. The shaft linings in the topsoil section adopt double-layer reinforced concrete, and there are gaps between the inner and outer shaft linings. After the completion of the shaft construction, due to the poor initial filling effect and the thawing of the frozen shaft linings, groundwater enters the inner and outer shaft lining spaces through the construction joints of the outer shaft linings. The single-layer shaft linings in the bedrock section 
TABLE 1: Original record form.

\begin{tabular}{lcccccccc}
\hline & \multicolumn{2}{c}{ Original (salt time 18:00) } & \multicolumn{3}{c}{ Salinity (measure time 21:00) } & \multicolumn{3}{c}{ Salinity (measure time 1:30) } \\
Number & Direction & Resistivity $(\Omega \cdot \mathrm{M})$ & Number & Direction & Resistivity $(\Omega \cdot \mathrm{M})$ & Number & Direction & Resistivity $(\Omega \cdot \mathrm{M})$ \\
\hline 1 & $0^{\circ}(\mathrm{N})$ & 84.44 & 1 & $0^{\circ}(\mathrm{N})$ & 84.46 & 1 & $0^{\circ}(\mathrm{N})$ & 84.50 \\
2 & $30^{\circ}$ & 79.75 & 2 & $30^{\circ}$ & 79.77 & 2 & $30^{\circ}$ & 79.70 \\
3 & $60^{\circ}$ & 79.73 & 3 & $60^{\circ}$ & 79.70 & 3 & $60^{\circ}$ & 79.68 \\
4 & $90^{\circ}(\mathrm{E})$ & 60.98 & 4 & $90^{\circ}(\mathrm{E})$ & 52.54 & 4 & $90^{\circ}(\mathrm{E})$ & 49.26 \\
5 & $120^{\circ}$ & 63.33 & 5 & $120^{\circ}$ & 46.91 & 5 & $120^{\circ}$ & 37.53 \\
6 & $150^{\circ}$ & 56.29 & 6 & $150^{\circ}$ & 37.53 & 6 & $150^{\circ}$ & 28.15 \\
7 & $180^{\circ}(\mathrm{S})$ & 51.60 & 7 & $180^{\circ}(\mathrm{S})$ & 39.87 & 7 & $180^{\circ}(\mathrm{S})$ & 32.37 \\
8 & $210^{\circ}$ & 51.63 & 8 & $210^{\circ}$ & 44.57 & 8 & $210^{\circ}$ & 37.53 \\
9 & $240^{\circ}$ & 56.28 & 9 & $240^{\circ}$ & 56.25 & 9 & $240^{\circ}$ & 56.20 \\
10 & $270^{\circ}(\mathrm{W})$ & 65.68 & 10 & $270^{\circ}(\mathrm{W})$ & 65.66 & 10 & $270^{\circ}(\mathrm{W})$ & 65.70 \\
11 & $300^{\circ}$ & 70.37 & 11 & $300^{\circ}$ & 70.39 & 11 & $300^{\circ}$ & 70.40 \\
12 & $330^{\circ}$ & 77.40 & 12 & $330^{\circ}$ & 77.41 & 12 & $330^{\circ}$ & 77.38 \\
\hline
\end{tabular}

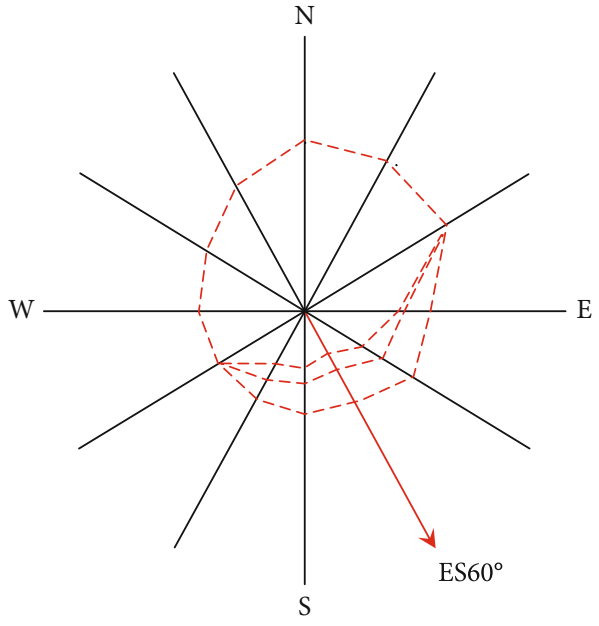

Figure 5: Water flow direction result graph.

groundwater directly gush into the shaft, but the topsoil section is affected by water pressure, and groundwater flows through the weak part of the inner shaft linings, resulting in serious gushing water. The main reason is that the blasting excavation of the shaft produces discontinuous plastic damage within a certain range of the surrounding rock, and the presence of hydraulic connection channels in the aquifer of the topsoil section results in the occurrence of crossgrouting and new gushing water points during the grouting and plugging process. On the other hand, the melting of the frozen soil around the shaft linings caused part of the formation to liquefy, and the topsoil section produces consolidation and settlement. The overall downward movement of the formation around the shaft is not synchronized with the vertical displacement of the shaft linings, which results in additional vertical additional stress [23-26] on the surface of the shaft linings. At the same time, when the temperature rises, the concrete of the shaft linings undergoes heat expansion and cold contraction, causing the gap to close, and the surrounding rock causes vertical compressive stress on the shaft linings, which causes the shaft linings to continue along with weak points such as stubble or annular gaps causing damage $[27,28]$.

\section{Monitoring of Water Flow Direction and Velocity}

3.1. Water Flow Direction Monitoring. To improve the effect of grouting and plugging gushing water, it is necessary to obtain data such as water flow direction and velocity. The water flow direction monitoring adopts a multifunctional digital electrical method, and a three-pole detection device is selected. To accurately control the water flow direction, 12 exploration lines are equally divided radially on the plane with the borehole as the center, and the angle between the lines is $30^{\circ}$. The plane layout is shown in Figure 4. Measure and record the electrical resistivity (potential difference) under natural conditions in a clockwise direction (N-E-S$\mathrm{W}$ ), and repeat salinization of shaft fluids in the borehole to observe the resistivity and potential changes; according to the changes in resistivity before and after salinization in different directions, the direction of resistivity decrease is the water flow direction, and the time consumed of resistivity reduction divided by the distance moved on the plane is the water velocity. The flow direction of the Quaternary water is $150^{\circ}\left(\mathrm{ES} 60^{\circ}\right)$, and the flow velocity is $0.73 \mathrm{~m} / \mathrm{h}$. The specific data is shown in Table 1 , and the water flow direction is shown in Figure 5.

\subsection{Flow Monitoring}

3.2.1. Measurement Range and Flow Measurement Method. The range of the main shaft for flow monitoring is $290.00 \sim 380.05 \mathrm{~m}$; the auxiliary shaft is $253.27 \sim 283.00 \mathrm{~m}$ (wind oxidation zone), $290.00 \sim 410.00 \mathrm{~m}$; and the mixed static water level is $15.06 \mathrm{~m}$.

Combined with the observation of pumping before flow measurement, the data shows that the pumping volume is small. The spot measurement method is adopted, and the distance between the measurement points is $2 \mathrm{~m}$; when the water flow changes, the measuring point spacing is encrypted 


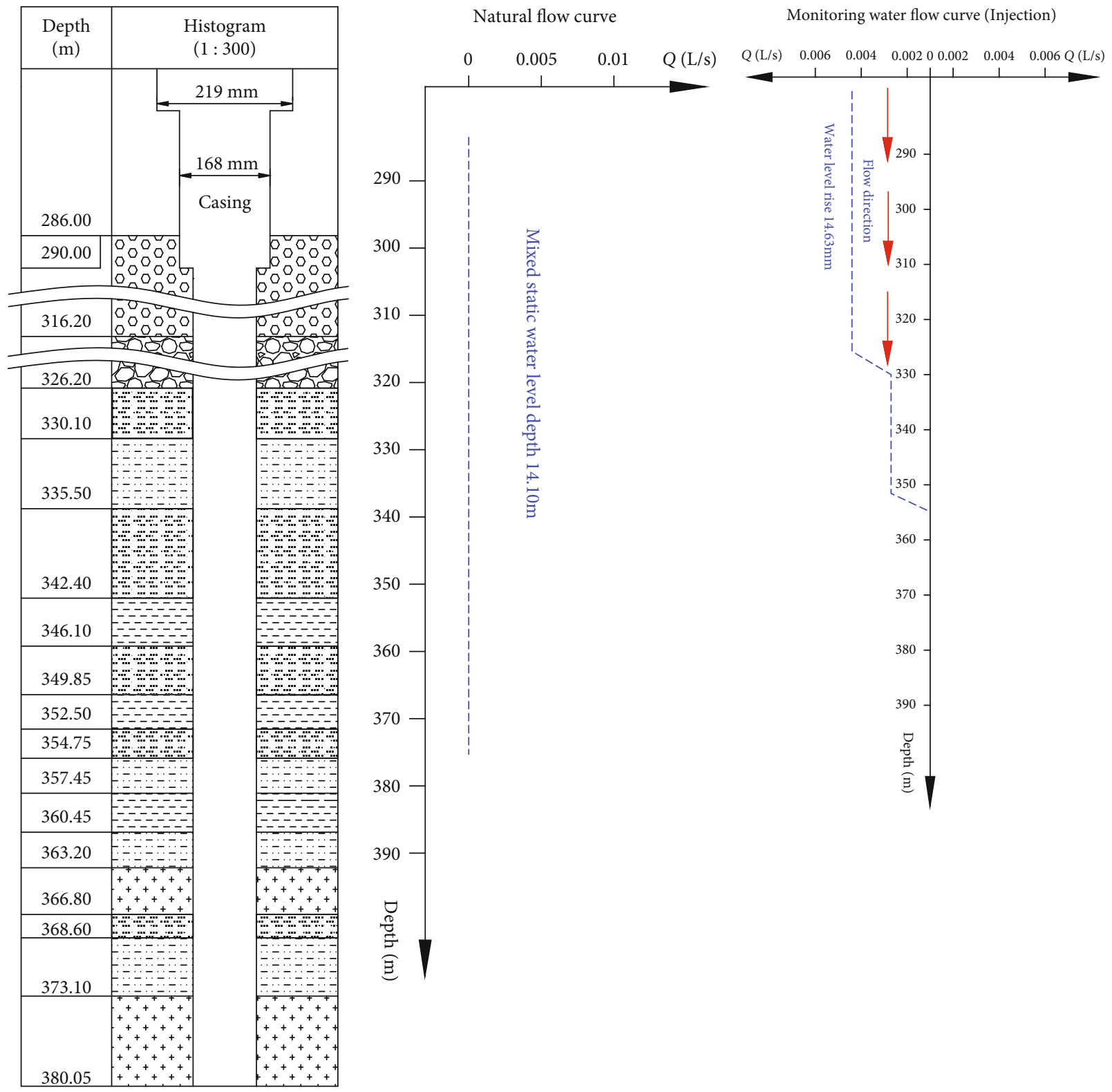

Magmatic rock

명

$\cdots$ Fine-grained

$\cdots . . .3$ sandstone

Mudstone

$+{ }_{++}^{+}$Siltstone

Sandy mudstone
(a) Histogram
(b) Natural flow
(c) Water injection

Figure 6: Flow curve diagram of the main shaft detection hole. 
TABLE 2: Main shaft aquifer parameters.

\begin{tabular}{|c|c|c|c|c|c|c|c|}
\hline Level & Top depth (m) & Bottom depth (m) & Thickness (m) & $\begin{array}{l}\text { Mixed dynamic } \\
\text { Layer flow (L/s) }\end{array}$ & $\begin{array}{l}\text { water level conditions } \\
\text { Cumulative flow }(\mathrm{L} / \mathrm{s})\end{array}$ & $\begin{array}{c}\text { Permeability } \\
\text { coefficient } K(\mathrm{~m} / \mathrm{d})\end{array}$ & $\begin{array}{c}\text { Influence } \\
\text { radius } R(\mathrm{~m})\end{array}$ \\
\hline 1 & 332.90 & 337.65 & 4.75 & -0.001788 & -0.005123 & 0.00167 & 6.10 \\
\hline 2 & 349.40 & 351.20 & 1.80 & -0.003335 & -0.003335 & 0.009756 & 14.74 \\
\hline
\end{tabular}

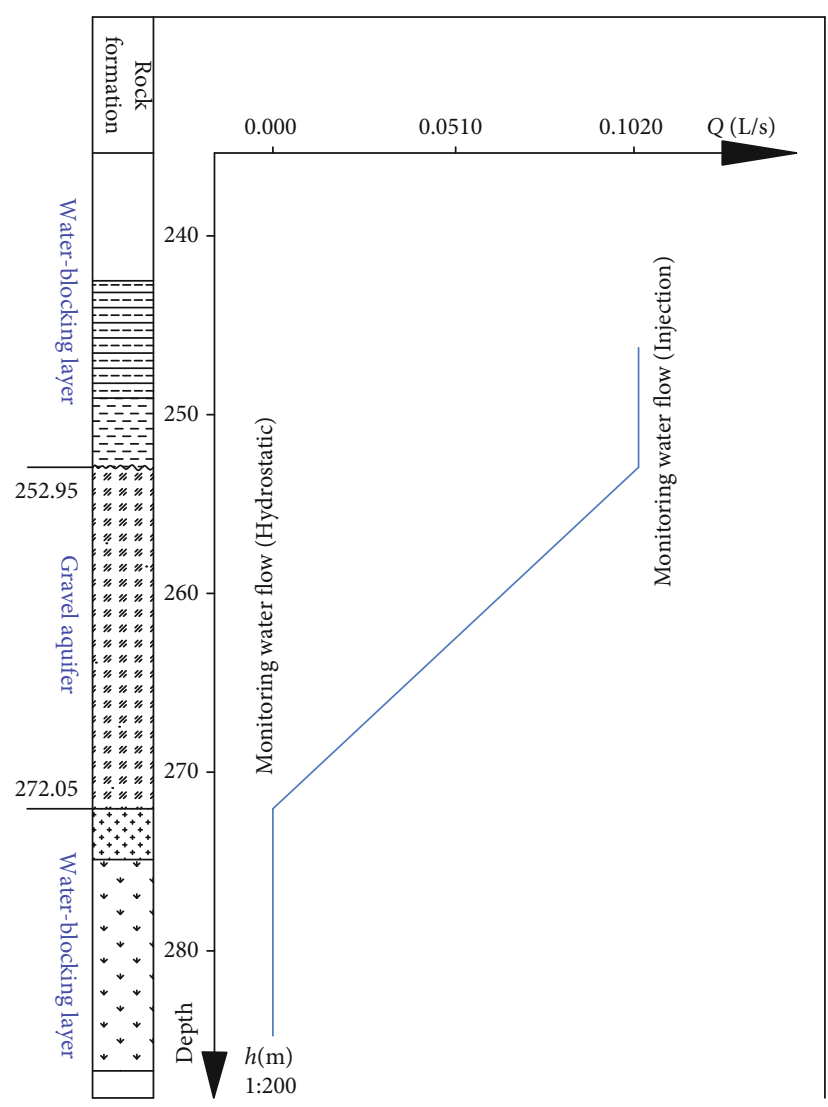

FIGURE 7: Flow monitoring diagram in the wind oxidation section of the auxiliary shaft.

to $0.5 \mathrm{~m}$, which is convenient for accurately dividing the depth and thickness of the aquifer.

3.2.2. Test Analysis. According to the field measurement data, the natural and water injection flow curve of the main shaft in the natural state is drawn, as shown in Figure 6.

Comprehensive analysis of the natural and water injection flow measurement curve data in Figure 6 shows the following:

(1) Monitoring the shaft section under static conditions, no water flow greater than the start-up sensitivity of the instrument was found, and the flow rate was zero, indicating that the static water level of the aquifer is not much different, or there is only one aquifer

(2) Under mixed water injection conditions, when the mixed water injection level is stable at $+0.53 \mathrm{~m}$ (uplifted by $14.63 \mathrm{~m}$ ), the wellhead water injection volume is $0.005347 \mathrm{~L} / \mathrm{s}$. The conversion data shows
TABLE 3: Water inflow of each measuring point.

\begin{tabular}{|c|c|c|}
\hline Depth (m) & $\begin{array}{l}\text { Natural water } \\
\text { inflow } Q(\mathrm{~L} / \mathrm{s})\end{array}$ & $\begin{array}{c}S=49.31 \mathrm{~m} \text { water } \\
\text { inflow } Q(\mathrm{~L} / \mathrm{s})\end{array}$ \\
\hline 250.00 & 0 & 0.1019 \\
\hline 252.00 & 0 & 0.1019 \\
\hline 252.50 & 0 & 0.1019 \\
\hline 253.00 & 0 & 0.1019 \\
\hline 254.00 & 0 & 0.0966 \\
\hline 256.00 & 0 & 0.0859 \\
\hline 258.00 & 0 & 0.0752 \\
\hline 260.00 & 0 & 0.0646 \\
\hline 262.00 & 0 & 0.0539 \\
\hline 264.00 & 0 & 0.0432 \\
\hline 266.00 & 0 & 0.0325 \\
\hline 268.00 & 0 & 0.0218 \\
\hline 270.00 & 0 & 0.0112 \\
\hline 270.50 & 0 & 0.0085 \\
\hline 271.00 & 0 & 0.0058 \\
\hline 271.50 & 0 & 0.0019 \\
\hline 272.00 & 0 & 0.0008 \\
\hline 272.50 & 0 & 0 \\
\hline 273.00 & 0 & 0 \\
\hline 274.00 & 0 & 0 \\
\hline 276.00 & 0 & 0 \\
\hline 278.00 & 0 & 0 \\
\hline 280.00 & 0 & 0 \\
\hline 282.00 & 0 & 0 \\
\hline 283.00 & 0 & 0 \\
\hline
\end{tabular}

that there are two confined aquifers, and because the static water level is lower than the water injection head, it appears as water absorption

(3) The depths of the two aquifers are 332.90 337.65 m and $349.40 \sim 351.20 \mathrm{~m}$, and the thickness is $4.75 \mathrm{~m}$ and $1.80 \mathrm{~m}$, respectively

For the main shaft inspection hole, combined with the Dupuit formula (1), according to the analysis of flow measurement curves during static and water injection, the parameters of the two aquifers are shown in Table 2.

$$
\begin{aligned}
& K=31.6224 Q \frac{\lg R-\ln r}{M S}, \\
& R=10.2 S \sqrt{K},
\end{aligned}
$$




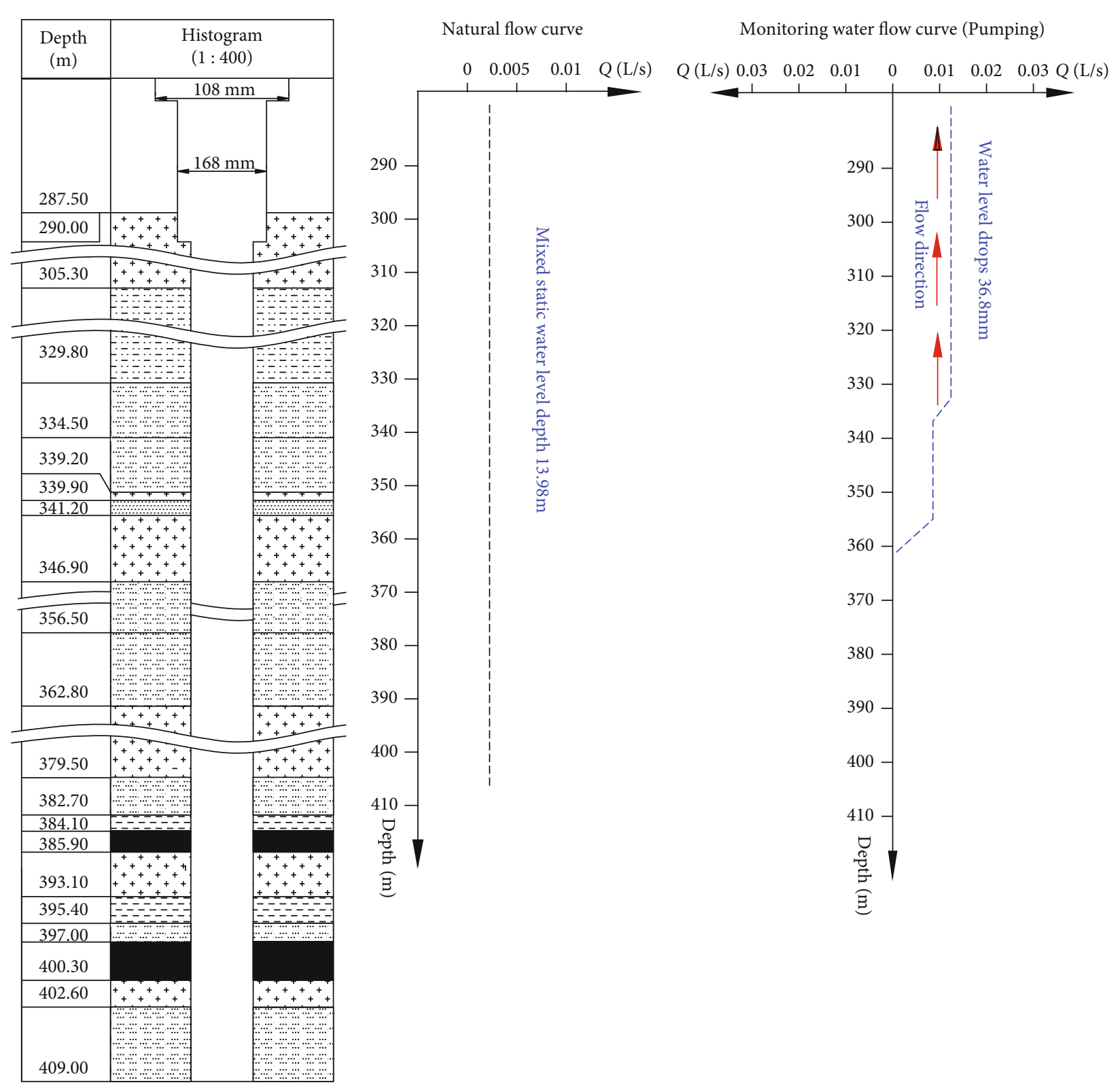

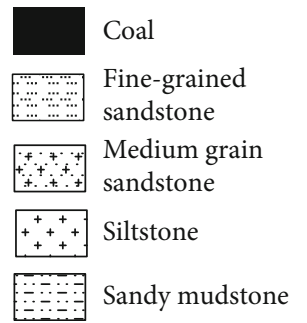

(a) Histogram 
TABLE 4: Auxiliary shaft aquifer parameters.

\begin{tabular}{|c|c|c|c|c|c|c|c|}
\hline Level & Top depth (m) & Bottom depth (m) & Thickness (m) & $\begin{array}{l}\text { Mixed dynamic } \\
\text { Layer flow }(\mathrm{L} / \mathrm{s})\end{array}$ & $\begin{array}{l}\text { water level conditions } \\
\text { Cumulative flow }(\mathrm{L} / \mathrm{s})\end{array}$ & $\begin{array}{c}\text { Permeability } \\
\text { coefficient } K(\mathrm{~m} / \mathrm{d})\end{array}$ & $\begin{array}{c}\text { Influence } \\
\text { radius } R(\mathrm{~m})\end{array}$ \\
\hline 1 & 334.70 & 340.40 & 5.70 & 0.011611 & 0.016667 & 0.004683 & 25.70 \\
\hline 2 & 357.10 & 360.90 & 3.80 & 0.005056 & 0.005056 & 0.002944 & 20.38 \\
\hline
\end{tabular}

to be producing water, with a horizon range of $252.95 \mathrm{~m}$ $272.05 \mathrm{~m}$, and the water inflow is $0.1019(\mathrm{~L} / \mathrm{s})$. The natural and pumping flow measurement data show that the horizon is in a static water state below $272.05 \mathrm{~m}$, indicating that this zone is a water barrier.

The natural and pumping flow curve in the natural state of the bedrock section is shown in Figure 8. The flow monitoring data shows the following:

(1) Under static conditions, no water inflow greater than the start-up sensitivity of the instrument was found in the measurement section, and the flow rate was zero, indicating that the static water level of the aquifer is not much different, or there is only one aquifer

(2) Under mixed pumping conditions, when the water level is stable at $50.81 \mathrm{~m}$, the water inflow from the shaft head is $0.01678 \mathrm{~L} / \mathrm{s}$

(3) It is measured by conversion data that there are two aquifers (confined aquifers) in the whole hole, which are expressed as gushing water. The depths of the two aquifers are $334.70 \sim 340.40 \mathrm{~m}$ and $357.10 \sim 360.90 \mathrm{~m}$, and the thickness is $5.70 \mathrm{~m}$ and $3.80 \mathrm{~m}$, respectively. The parameters of the two aquifers in the auxiliary inspection hole are calculated by the Dupuit formula as shown in Table 4

\section{Numerical Simulation of the Groundwater Seepage Field}

4.1. Numerical Model Establishment. Combining the geological conditions and the structure of the shaft, the $X$ and $Y$ directions of the calculation model are $150 \mathrm{~m}$, and the $Z$ direction is $500 \mathrm{~m}$. The model is divided into 115080 units and 116443 nodes. Horizontal constraints are imposed on the side boundary of the model; horizontal and vertical constraints are imposed on the bottom boundary. To comprehensively analyze the stress field, deformation, and failure characteristics of the shaft surrounding rock, a combination model of different rock formations and water pressures is established. The top surface of the water-bearing rock mass is based on the water level line as the upper boundary, and the water outlet point is near the stubble of the shaft. The fissures in the rock are the main runoff channels for groundwater and are important parts of grouting and plugging. At the same time, to facilitate the calculation, the floor elevation of the water-bearing rock mass is set to a fixed value, and a three-dimensional numerical calculation model is adopted. The grid diagram is shown in Figure 9.

According to the field geological drilling data and rock mechanics test results, the Mohr-Coulomb yield criterion

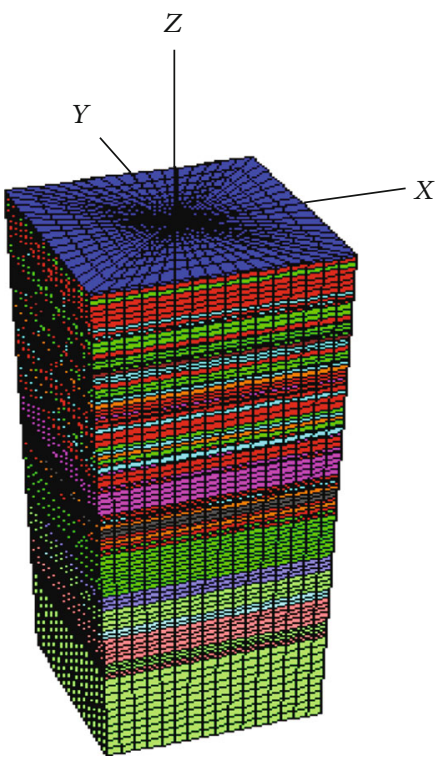

Figure 9: Three-dimensional numerical calculation model.

and the solid-liquid coupling calculation model are used. The lithological physical and mechanical parameters of the rock layer are shown in Table 5.

4.2. Simulation Calculation Scheme. This simulation considers the effect of the water bodies and adopts the solidliquid coupling calculation mode. After the static calculation is stable, the coupling calculation is performed to consider the influence of the confined water. The simulation advances $5 \mathrm{~m}$ as a calculation time step to realize segmented construction, and the water pressure is set to 0.5 times, 1 time, and 2 times of the original hydrostatic pressure.

\subsection{Simulation Result Analysis}

4.3.1. Regardless of Solid-Liquid Coupling. Figures 10-12 show the stress, displacement, and deformation of the shaft surrounding rock without considering the action of water bodies. Figure 10 reveals that there is a nonlinear relationship between stress change and depth, showing a wavelike state. The maximum tensile stress is $1.85 \mathrm{MPa}$, and the maximum compressive stress is $3.67 \mathrm{MPa}$. Figure 11 shows that the horizontal displacement is symmetrical along the shaft section. The direction of the displacement vector points to the inner shaft lining. There is a nonlinear relationship between the change in horizontal displacement and the shaft depth, and the maximum horizontal displacement is $14 \mathrm{~mm}$. The vertical displacement shows a decreasing trend with the increase of the shaft depth. The maximum vertical displacement 
TABLE 5: Lithological physical and mechanical parameters.

\begin{tabular}{|c|c|c|c|c|c|c|c|}
\hline Lithology & Thickness (m) & $\begin{array}{c}\text { Shear modulus } \\
(\mathrm{GPa})\end{array}$ & $\begin{array}{l}\text { Bulk modulus } \\
\qquad(\mathrm{GPa})\end{array}$ & $\begin{array}{c}\text { Cohesion } \\
(\mathrm{MPa})\end{array}$ & $\begin{array}{l}\text { Internal friction } \\
\text { angle }\left(^{\circ}\right)\end{array}$ & $\begin{array}{c}\text { Tensile strength } \\
(\mathrm{MPa})\end{array}$ & Density $\left(\mathrm{kg} \cdot \mathrm{m}^{-3}\right)$ \\
\hline Humus & 2.26 & 0.13 & 0.58 & 1.20 & 15 & 0.82 & 1800 \\
\hline Clay & 108.00 & 0.15 & 0.44 & 2.82 & 18 & 0.82 & 1850 \\
\hline Gravel grit & 91.25 & 0.07 & 0.15 & 0.00 & 32 & 0.82 & 2000 \\
\hline Coarse sand & 31.53 & 0.14 & 0.23 & 0.01 & 40 & 0.82 & 2200 \\
\hline Fine sand & 32.64 & 0.07 & 0.14 & 0.00 & 35 & 0.82 & 2000 \\
\hline Silty clay & 3.84 & 0.21 & 0.79 & 1.50 & 18 & 0.82 & 1800 \\
\hline Sandy clay & 20.19 & 12.40 & 17.24 & 2.52 & 25 & 0.82 & 2200 \\
\hline Siltstone & 9.57 & 19.12 & 24.46 & 9.60 & 31 & 4.31 & 2545 \\
\hline Mudstone & 36.42 & 1.86 & 2.96 & 1.50 & 22 & 0.55 & 2100 \\
\hline Medium sandstone & 10.85 & 0.79 & 1.52 & 2.20 & 25 & 0.60 & 1400 \\
\hline Fine sandstone & 134.69 & 25.84 & 33.06 & 12.00 & 34 & 6.12 & 2700 \\
\hline Magmatic rock & 16.23 & 31.01 & 39.68 & 14.40 & 40.8 & 7.34 & 2700 \\
\hline
\end{tabular}

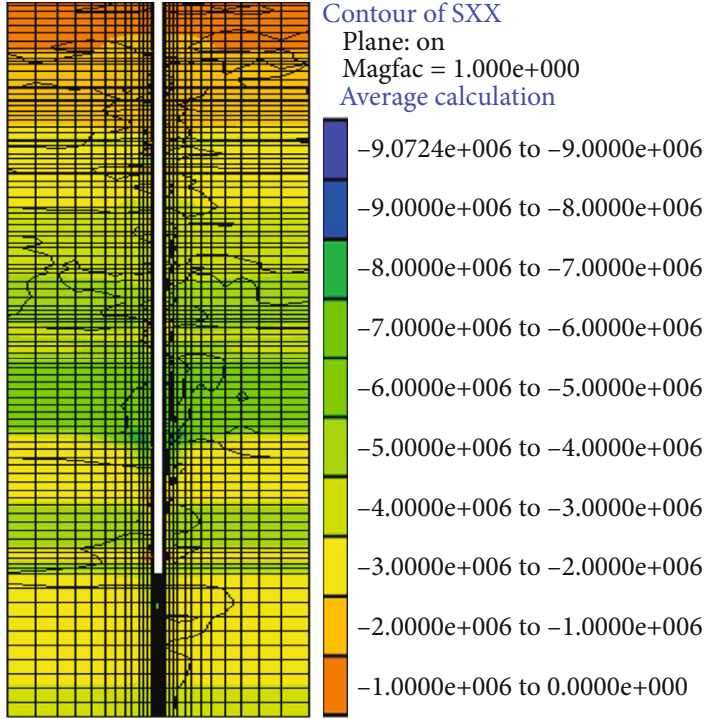

(a) Horizontal stress

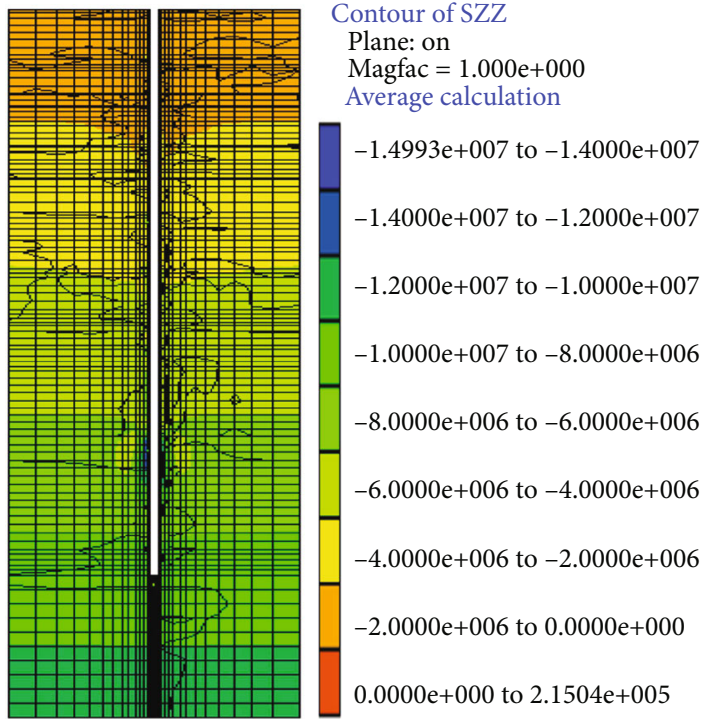

(b) Vertical stress

FIGURE 10: Shaft surrounding rock stress.

mostly occurs in the shallow part of the shaft, and the maximum sinking value is $7.5 \mathrm{~mm}$.

Figure 12 shows the deformation and failure of the shaft surrounding rock without considering the action of the water bodies. The surrounding rock deformation is due to the stress release caused by the shaft construction, resulting in secondary stress distribution. Plastic failure occurs in some sections, and the damage points are concentrated in the upper part of the shaft, which is consistent with the current water outlet point.

4.3.2. Simulation Analysis considering Coupling. Figures 1317 , respectively, describe the stress, displacement, and plastic failure changes in the shaft surrounding rock, considering the action of the water bodies, and the water pressure is $0.5,1$, and 2 times the original hydrostatic pressure.
Figures 13 and 14 show that there is a nonlinear relationship between the surrounding rock stress and shaft depth. At the same time, the stress changes in local sections are relatively large, which shows that there is a great relationship with the lithology of the shaft surrounding rock. The horizontal stress simultaneously appears with tensile stress and compressive stress in different areas of the shaft, the maximum tensile stress is $1.54 \mathrm{MPa}$, and the maximum compressive stress is $4.28 \mathrm{MPa}$. In general, the stress of the surrounding rock increases with the water pressure increase, and the horizontal stress increases by 3.89 times.

Figures 15 and 16 show that there is a nonlinear relationship between the displacement of the surrounding rock and the shaft depth. With the increase of water pressure, the horizontal displacement of the shaft surrounding rock increases, while the vertical displacement decreases When 


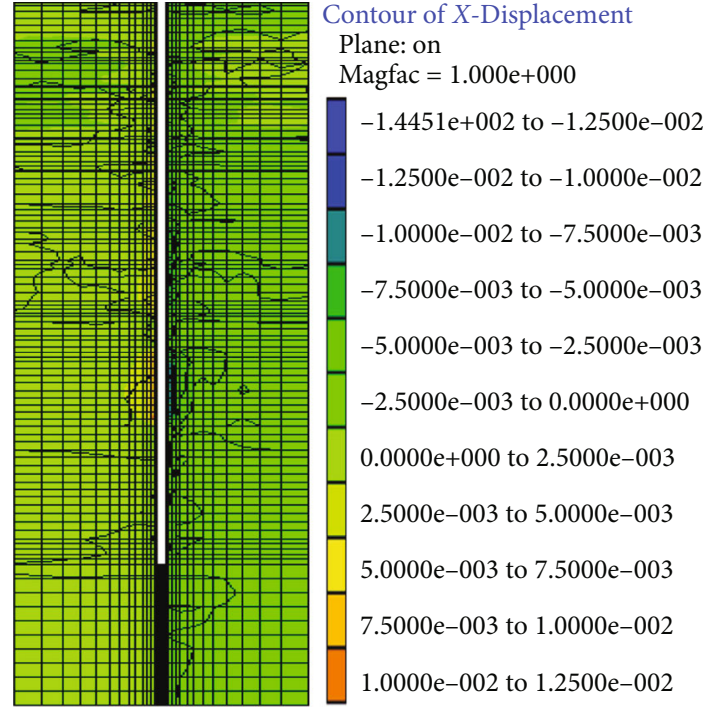

(a) Horizontal displacement

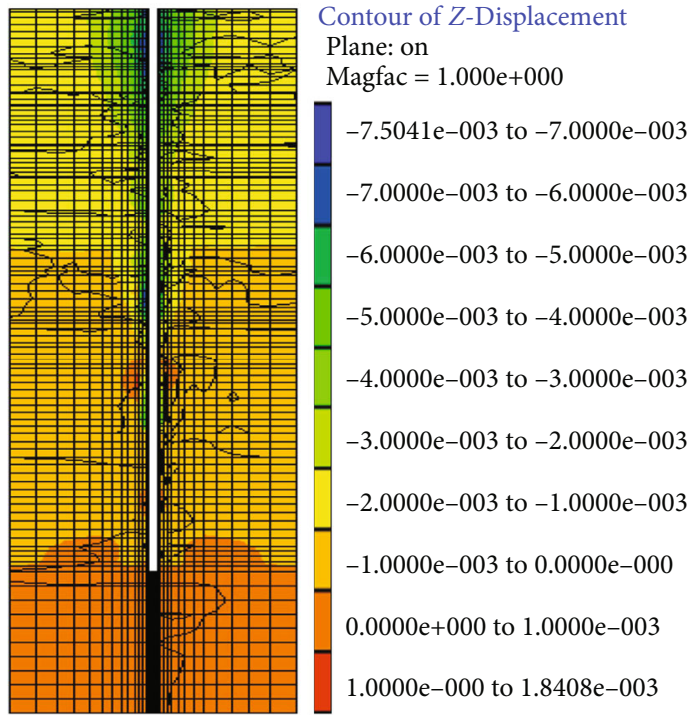

(b) Vertical displacement

FIGURE 11: Shaft surrounding rock displacement.

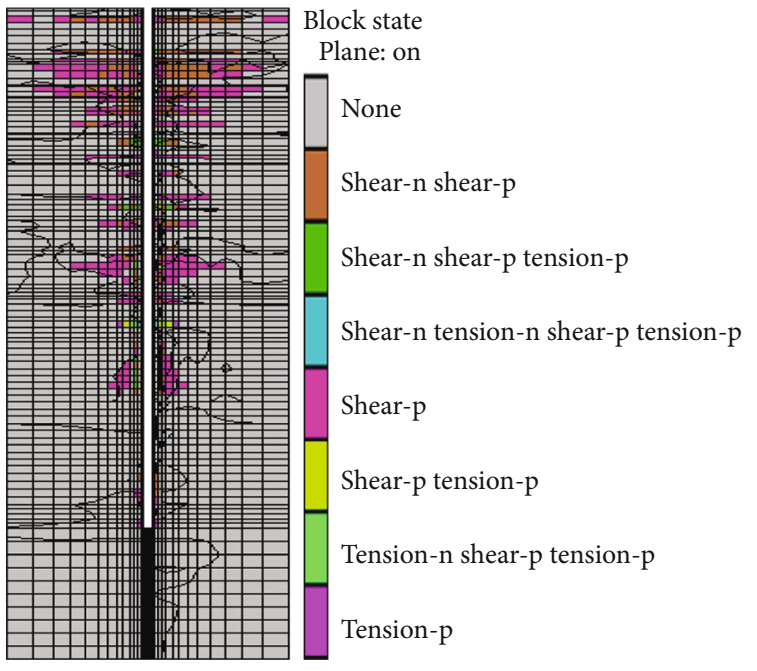

Figure 12: Plastic zone of the shaft surrounding rock.

the water pressure is $0.5,1$, and 2 times of the hydrostatic pressure, the maximum horizontal displacement is $17.526 \mathrm{~mm}$, $17.528 \mathrm{~mm}$, and $19.79 \mathrm{~mm}$, and the maximum vertical displacement is $70.451 \mathrm{~mm}, 70.316 \mathrm{~mm}$, and $65.894 \mathrm{~mm}$, respectively.

Figure 17 shows that with the increase of water pressure, the plastic damage range, and the damage degree of the shaft surrounding rock increases, the damage position roughly corresponds to the current water outlet point position.

\section{Grouting Construction Plan and Technological Design}

5.1. Grouting Material Selection. Malisan $\mathrm{N}$ is a low-viscosity, two-component synthetic polymer-polyimide resin material. Malisan $\mathrm{N}$ and its catalyst are configured to form liquid slurry in a ratio of $1: 1$. The topsoil section adopts interwall grouting, and the bedrock section adopts high-pressure pouring slurry to replace fracture water, plug sandstone water, fill pores, and squeeze and reinforce the shaft surrounding rock to achieve the purpose of preventing leakage. Use different testing instruments to conduct experimental research on Malisan $\mathrm{N}$ and grouting samples. The specific grouting material parameters are shown in Tables 6-10.

The above data shows that the grouting material has good fluidity, permeability, cohesion, and swelling properties and has high strength. The grouting material has fast gelation velocity; the slurry quickly penetrates the tiny pores and expands by 20 times when exposed to water. Finally, the consolidation of the slurry can form a whole with the surrounding rock to meet the needs of the construction requirements.

5.2. Grouting Drilling Layout. The drilling is arranged at the water outlet point or within $0.5 \mathrm{~m}$ of the water outlet point, using grouting behind the shaft linings; the hole depth is $1.0 \sim 1.5 \mathrm{~m}$; and the elevation angle is $10 \sim 20^{\circ}$. The sealing device is installed after the hole is formed by the pneumatic drill. The sealing device is made of steel pipe and expanded rubber, with a length of $280 \mathrm{~mm}$ and a diameter of $\Phi=38 \mathrm{~mm}$. The rubber swells up during grouting, and the hole is sealed under pressure.

Each section is designed with four holes, the grouting drilling diameter is $42 \mathrm{~mm}$, the drilling spacing is $2.3 \mathrm{~m}$, the grout diffusion radius is $4.2 \mathrm{~m}$, and the height of the grouting section is $3 \mathrm{~m}$. The grouting section is mainly concentrated in the shaft depth of $90 \sim 110 \mathrm{~m}, 180 \sim 210 \mathrm{~m}, 270 \sim 300 \mathrm{~m}$, and $320 \sim 360 \mathrm{~m}$. This grouting has plugged twelve water outlet points, seven topsoil sections, and five bedrock sections. A total of 48 holes are designed. The specific layout of the grouting drilling is shown in Figure 18.

\subsection{Grouting and Water-Blocking Construction Technology}

5.3.1. Grouting Equipment. The grouting equipment includes the grouting pumps, drilling machinery, mixers, packer, and 


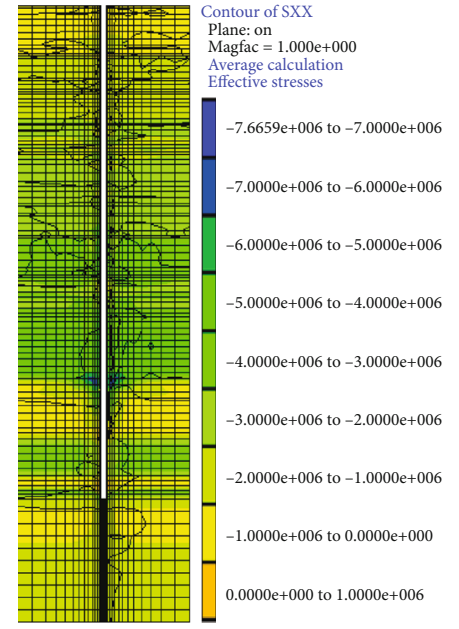

(a) $P_{\mathrm{w}}=0.5 P_{\mathrm{s}}$

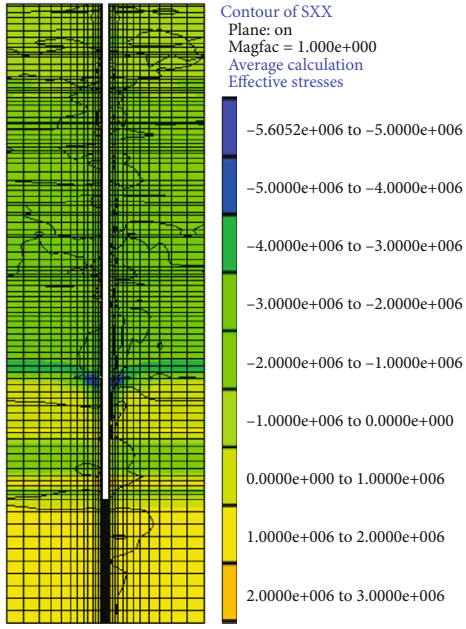

(b) $P_{\mathrm{w}}=1.0 P_{\mathrm{s}}$

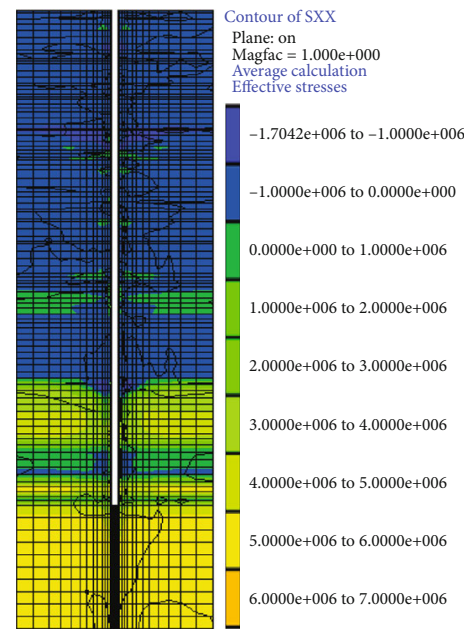

(c) $P_{\mathrm{w}}=2.0 P_{\mathrm{s}}$

FIgURE 13: Horizontal stress.

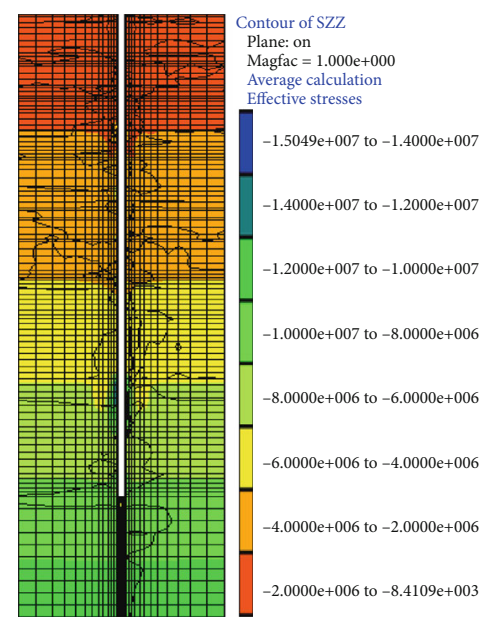

(a) $P_{\mathrm{w}}=0.5 P_{\mathrm{s}}$

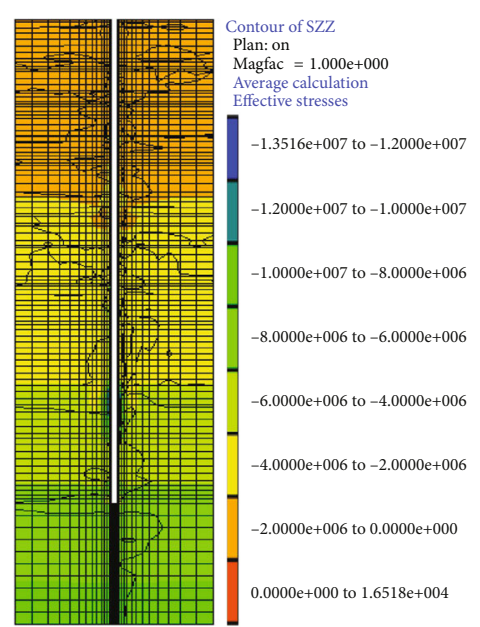

(b) $P_{\mathrm{w}}=1.0 P_{\mathrm{s}}$

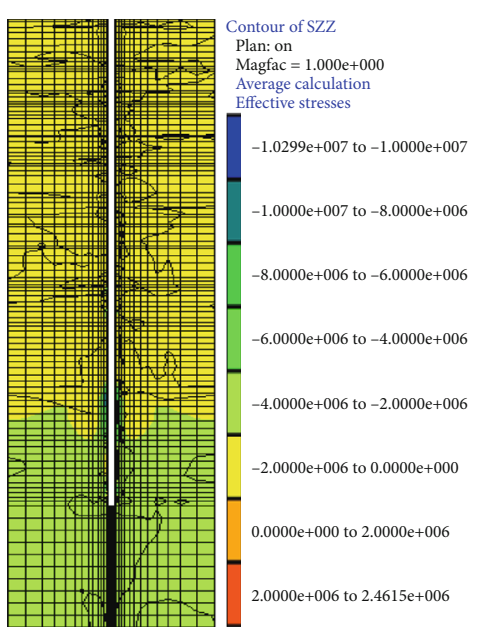

(c) $P_{\mathrm{w}}=2.0 P_{\mathrm{s}}$

FIgURE 14: Vertical stress.

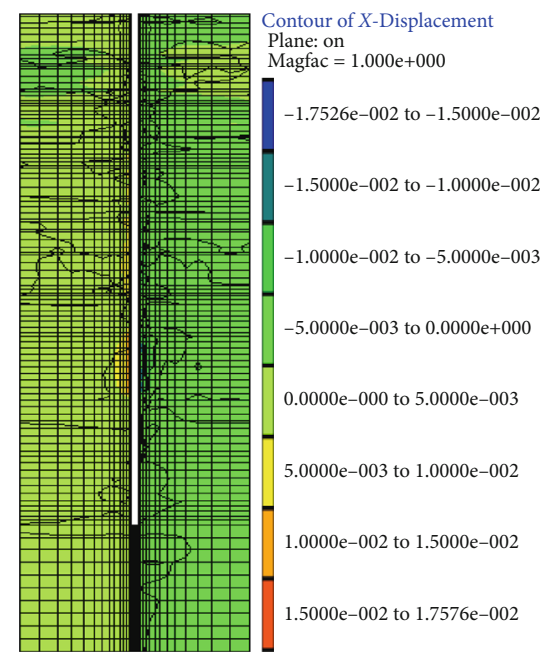

(a) $P_{\mathrm{w}}=0.5 P_{\mathrm{s}}$

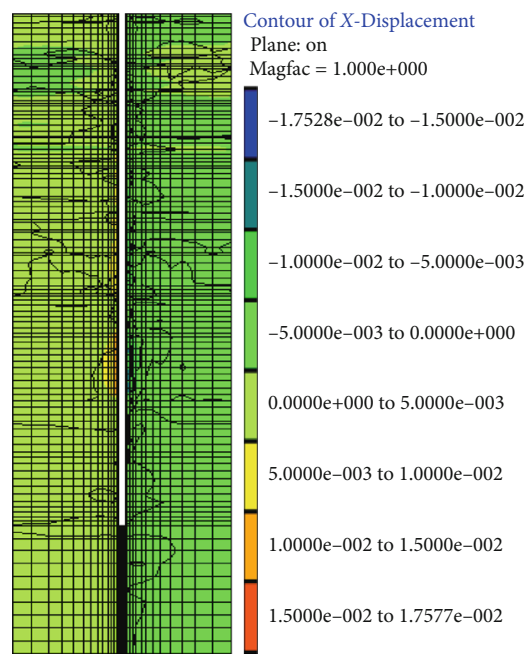

(b) $P_{\mathrm{w}}=1.0 P_{\mathrm{s}}$

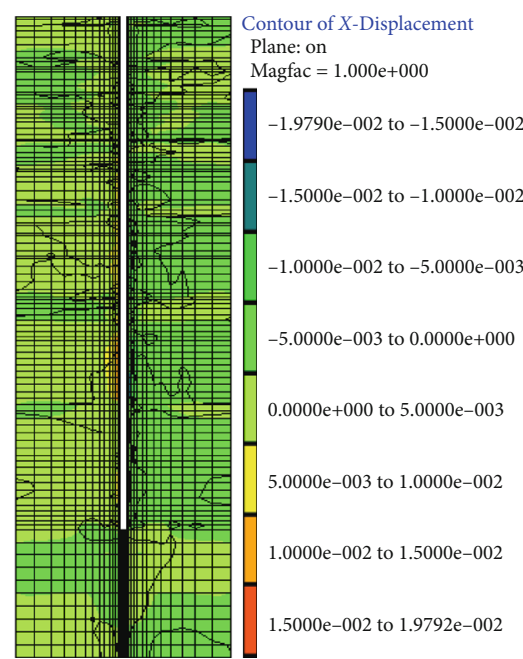

(c) $P_{\mathrm{w}}=2.0 P_{\mathrm{s}}$

Figure 15: Horizontal displacement. 


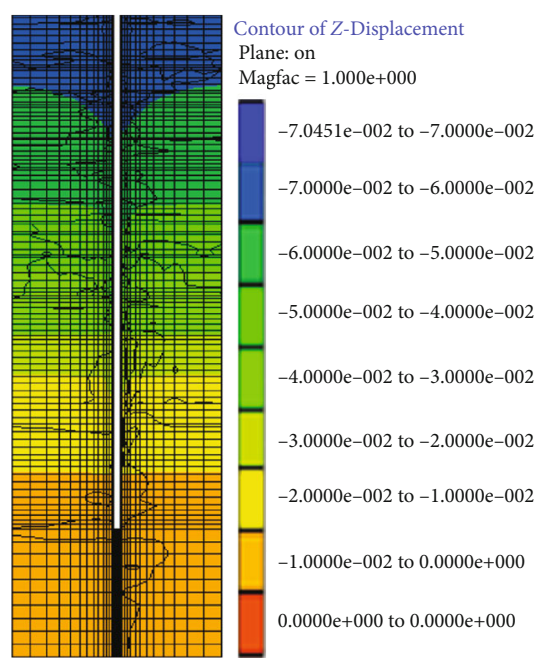

(a) $P_{\mathrm{w}}=0.5 P_{\mathrm{s}}$

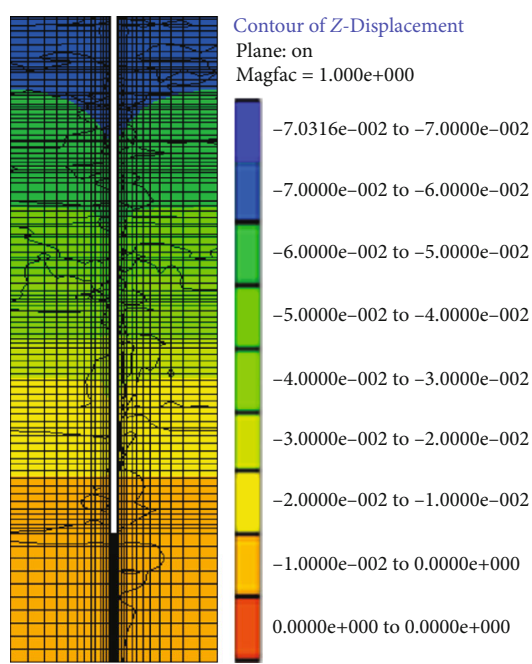

(b) $P_{\mathrm{w}}=1.0 P_{\mathrm{s}}$

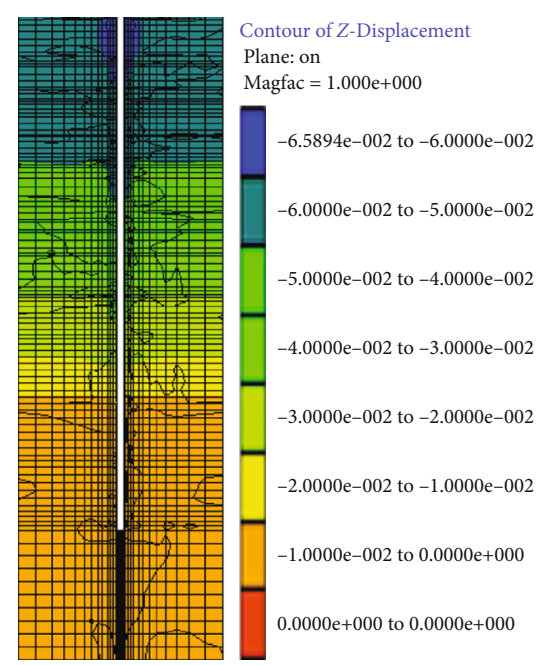

(c) $P_{\mathrm{w}}=2.0 P_{\mathrm{s}}$

Figure 16: Vertical displacement.

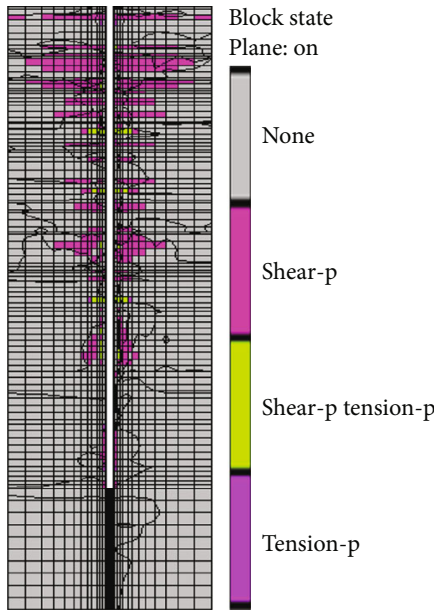

(a) $P_{\mathrm{w}}=0.5 P_{\mathrm{s}}$

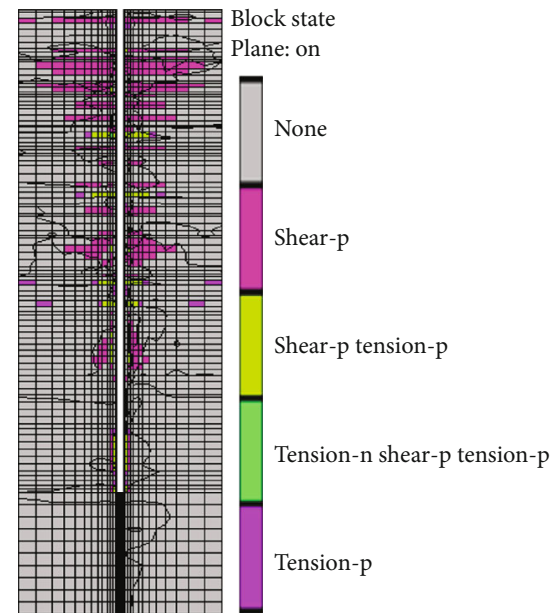

(b) $P_{\mathrm{w}}=1.0 P_{\mathrm{s}}$

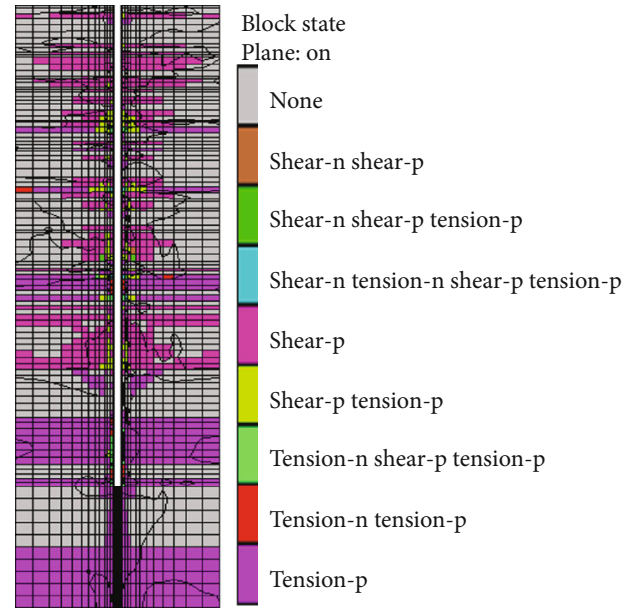

(c) $P_{\mathrm{w}}=2.0 P_{\mathrm{s}}$

FIgURe 17: Plastic damage.

TABLE 6: Malisan N basic data

\begin{tabular}{lcc}
\hline Basic ingredients & Resin & Catalyst \\
\hline Density at $25^{\circ} \mathrm{C}\left(\mathrm{g} / \mathrm{cm}^{3}\right)$ & 1.04 & 1.23 \\
Viscosity at $25^{\circ} \mathrm{C}(\mathrm{MPa} \cdot \mathrm{s})$ & 200 & 210 \\
Mixing ratio (volume ratio) & 1 & 1 \\
Shelf life at $20^{\circ} \mathrm{C}($ month) & 6 & 6 \\
Storage temperature $\left({ }^{\circ} \mathrm{C}\right)$ & $5 \sim 300$ & $5 \sim 300$ \\
\hline
\end{tabular}

necessary instruments. The grouting pump adopts a special small air pump with a size of $1.16 \mathrm{~m} \times 0.41 \mathrm{~m} \times 0.41 \mathrm{~m}$ (Figure 19). The wind source is used as the grouting power, the wind pressure is $0.4 \sim 0.8 \mathrm{MPa}$, the pump capacity is $5.2 \mathrm{~L} / \mathrm{min}$, the slurry obtains 12.5 times the wind pressure during the grouting process, and the pumping distance of the air pump can reach at least $40 \mathrm{~m}$.

Malisan $\mathrm{N}$ accessories mainly include two high-pressure pipes, an injection gun, a standard injection tube, and a self-
TABLE 7: Malisan N performance data.

\begin{tabular}{lcc}
\hline Aggregate products & & \\
\hline Application temperature $\left({ }^{\circ} \mathrm{C}\right)$ & $15^{\circ}$ & $25^{\circ}$ \\
Initial viscosity $(\mathrm{MPa} \cdot \mathrm{s})$ & 450 & 250 \\
Start to react (minute) & $1: 15$ & $0: 45$ \\
End of foaming (minute) & $2: 10$ & $1: 25$ \\
Expansion ratio & 2 & 2 \\
Pressure $(\mathrm{MPa})$ & $>15$ & $>15$ \\
Adhesion $(\mathrm{MPa})$ & $>5$ & $>5$ \\
\hline
\end{tabular}

locking oil seal. The injection gun adopts a two-liquid injection mixing gun composed of a static mixer, homomixer, one-way valve, ball valve, etc., and a loop self-punching sealing device is used for grouting and sealing the hole.

5.3.2. Grouting Construction Technology. For grouting construction, use cages to build a workbench, and prepare 
TABLE 8: Uniaxial compressive strength test.

\begin{tabular}{ccccccc}
\hline \multirow{2}{*}{ No. } & \multicolumn{3}{c}{ Specimen size $(\mathrm{mm})$} & \multicolumn{2}{c}{} & \\
Length & Width & Height & Plastic deformation starting load value $(\mathrm{kN})$ & Maximum breaking load (kN) & Compressive strength (MPa) \\
\hline 1 & 50 & 50 & 100 & 160.1 & 166.7 & 66.7 \\
2 & 50 & 50 & 100 & 150.9 & 158.6 & 63.4 \\
3 & 50 & 50 & 100 & 151.9 & 168.4 & 67.4 \\
\hline
\end{tabular}

TABLE 9: Shear strength test.

\begin{tabular}{|c|c|c|c|c|c|c|c|c|c|}
\hline \multirow{2}{*}{ No. } & \multicolumn{3}{|c|}{ Specimen size $(\mathrm{mm})$} & \multirow{2}{*}{ Shear angle $\left({ }^{\circ}\right)$} & \multirow{2}{*}{ Failure load $(\mathrm{kN})$} & \multirow{2}{*}{$\begin{array}{l}\text { Maximum normal } \\
\text { stress }(\mathrm{MPa})\end{array}$} & \multirow{2}{*}{$\begin{array}{c}\text { Maximum shear } \\
\text { stress }(\mathrm{MPa})\end{array}$} & \multirow{2}{*}{$\begin{array}{c}\text { Internal friction } \\
\text { angle }\left({ }^{\circ}\right)\end{array}$} & \multirow{2}{*}{ Cohesion $(\mathrm{MPa})$} \\
\hline & Length & Width & Height & & & & & & \\
\hline 1 & 70 & 70 & 70 & 55 & 188.6 & 22.1 & 31.5 & 45 & 10.2 \\
\hline 2 & 70 & 70 & 70 & 60 & 167.9 & 17.1 & 29.7 & 45 & 10.2 \\
\hline 3 & 70 & 70 & 70 & 65 & 108.4 & 9.35 & 20.1 & 45 & 10.2 \\
\hline
\end{tabular}

TABLe 10: Uniaxial tensile strength test.

\begin{tabular}{|c|c|c|c|c|c|c|}
\hline \multirow{2}{*}{ No. } & \multicolumn{2}{|c|}{ Specimen size $(\mathrm{mm})$} & \multirow{2}{*}{ Failure load (kN) } & \multirow{2}{*}{ Average tensile strength $(\mathrm{MPa})$} & \multirow{2}{*}{ Deformation $(\mathrm{mm})$} & \multirow{2}{*}{ Extension rate (\%) } \\
\hline & Diameter & Length & & & & \\
\hline 1 & 22 & 180 & 17.0 & 44.7 & 8.61 & 4.78 \\
\hline 2 & 22 & 180 & 13.2 & 34.7 & 5.67 & 3.15 \\
\hline 3 & 22 & 190 & 15.6 & 41.0 & 6.72 & 3.54 \\
\hline
\end{tabular}

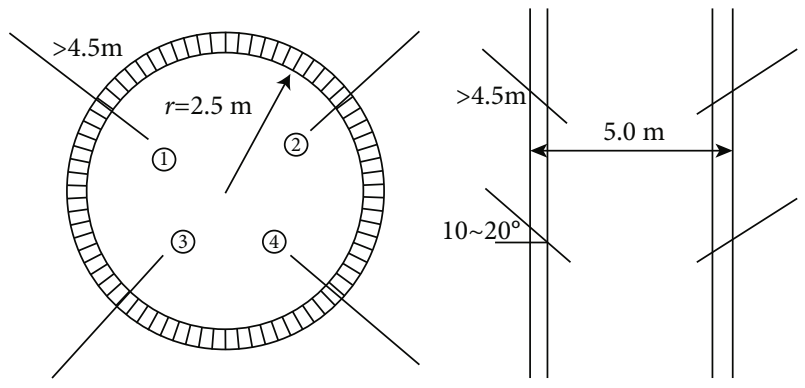

FIGURE 18: Schematic diagram of the grouting drilling layout.

construction equipment and materials on the workbench. The " $8 \mathrm{~h} / \mathrm{d}$ " operation system is adopted, with a total of six operators: three persons are responsible for grouting technology and equipment operation, and three persons are responsible for shaft lining drilling construction, water source tracking, material preparation, and other grouting auxiliary operations. The shaft grouting construction sequence adopts downward grouting, plugging the upper water outlet point first then the lower water outlet point, and finally plugging the middle. The shaft lining thickness of the water outlet section is $450 \mathrm{~mm}$; the drilling depth should be greater than $450 \mathrm{~mm}$ to ensure that the borehole penetrates the shaft linings. The depth of the self-locking oil seal that extends into the hole is $200 \mathrm{~mm}$, and use quick-setting cement to block grouting holes and nonoutlet holes after grouting.

Preliminary preparation for grouting is completed, connect the air passage and grouting pipeline, start the grouting pump, suck in Malisan $\mathrm{N}$ and its catalyst according to the mixing ratio of $1: 1$ (volume ratio), and press them into the

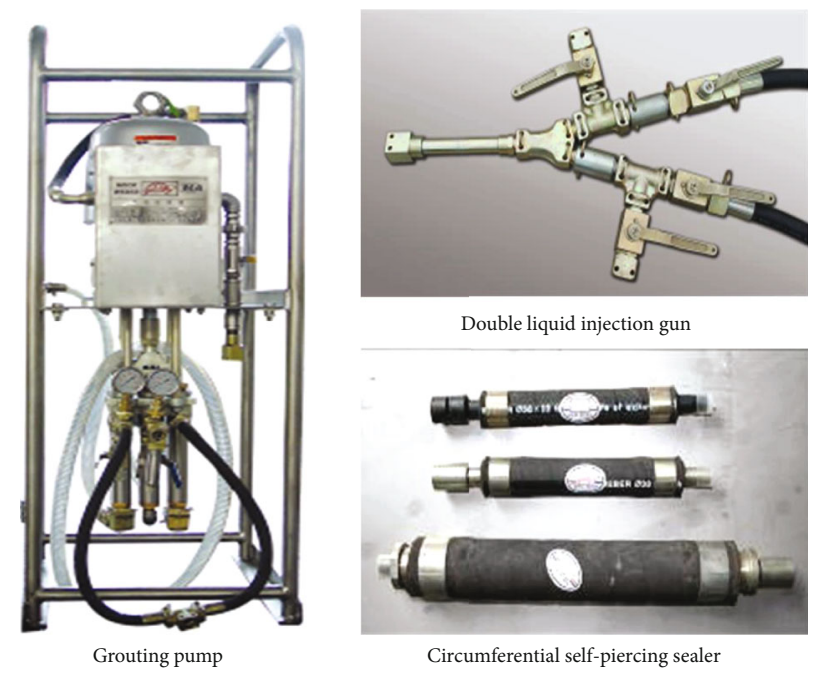

FIGURE 19: Grouting equipment.

equalizing mixer at the front of the injection gun. The grouting pressure should be $0.5 \sim 1.0 \mathrm{MPa}$ higher than the hydrostatic pressure at the water outlet point. After uniform mixing and standard injection, the high-pressure mixed liquid is instantly pressurized in the self-locking oil seal, and part of the liquid enters the gap between the steel pipe and the expanded rubber, causing the rubber to swell up and stick to the hole wall. The mixed liquid rapidly foams and expands in the cavity to complete the self-locking oil seal. After the mixed slurry enters the gushing cavity and cracks behind shaft linings, a series of plugging processes (spreads, fills, foams, and solidifies) are completed. The specific process flow is shown in Figure 20. 


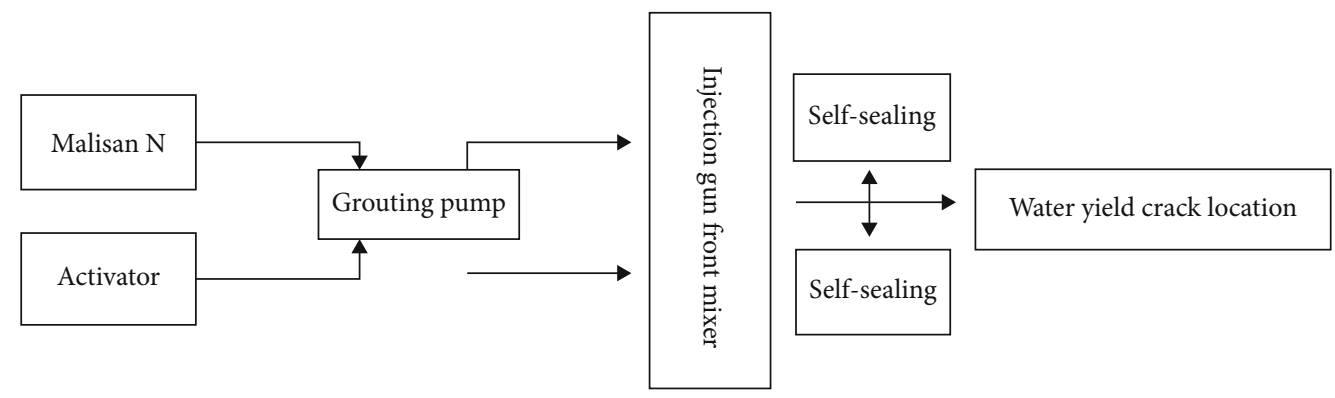

FIGURE 20: Grouting process flow chart.

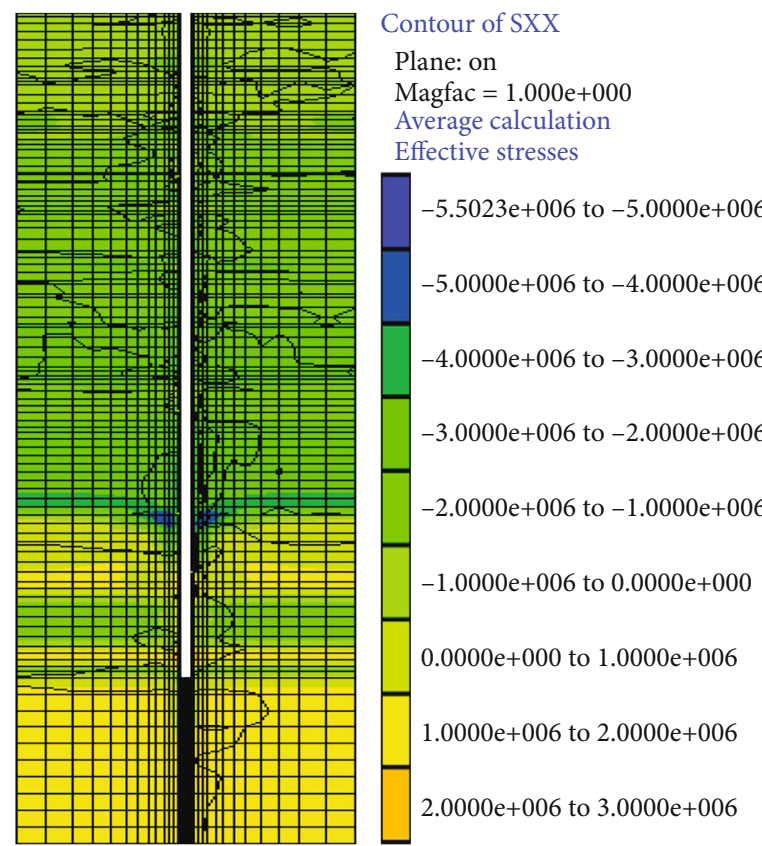

(a) Horizontal stress

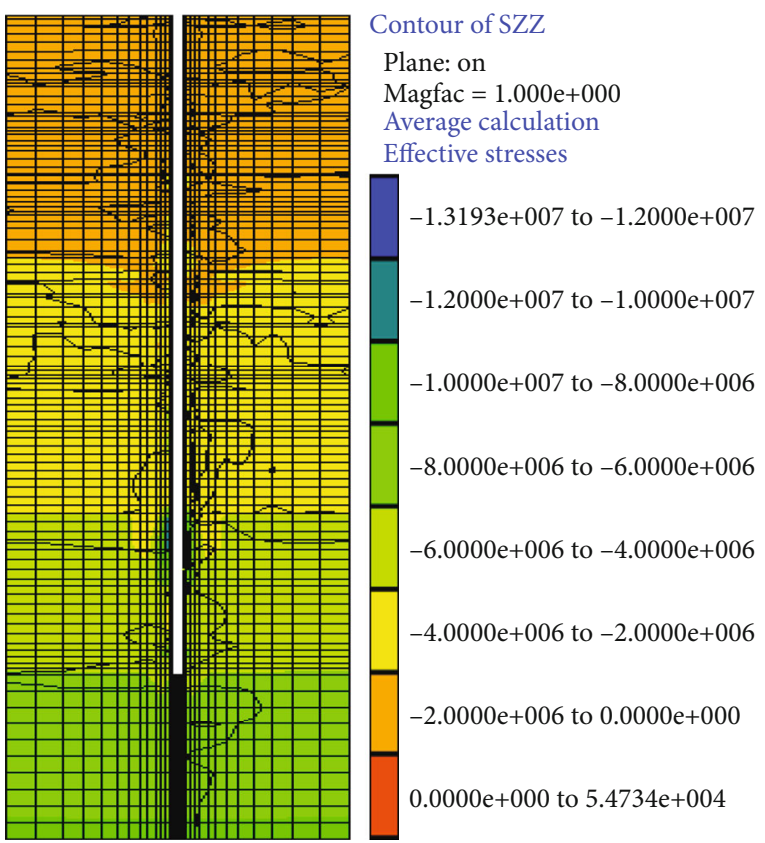

(b) Vertical stress

FIGURE 21: Shaft surrounding rock stress.

\section{Engineering Application Effect Analysis}

6.1. Groundwater Level Change. According to the monitoring data, the water level in the observation hole changes with seasonal fluctuations, the rainy season rises and the dry season decreases. With the implementation of the shaft grouting, the water level in the observation hole gradually increases. The measured water level line shows that the shaft grouting effect is obvious.

6.2. Slurry Diffusion Radius. According to the measured data, obtain the cross-grout distance of the slurry diffusion radius.

(1) The slurry diffusion radius in conglomerate and glutenite ranges is $7.0 \sim 77.0 \mathrm{~m}$, and the effective diffusion radius is greater than $7.0 \sim 8.5 \mathrm{~m}$. The data shows that conglomerate and glutenite have strong internal connectivity; the range of slurry diffusion and slurry consumption is large
(2) The slurry diffusion radius in the weathered sandstone layer, pseudointegrated sandstone layer, and sandstone layer ranges is $2.4 \sim 80.0 \mathrm{~m}$, and the effective diffusion radius is greater than $6.0 \sim 7.5 \mathrm{~m}$. The average number of vertical observations of the abovementioned rock formations is gradually reduced, from 22 to 8 , and the degree of fracture development and connectivity decreased with the depth increase

Combined with the above data, to shorten the construction period and ensure the quality of grouting, a single row of grouting holes is used, and the slurry diffusion radius is controlled at $4.2 \mathrm{~m}$.

6.3. Numerical Simulation Analysis of the Grouting Effect. Figure 21 depicts that after the shaft grouting is completed, considering the action of the water bodies, the water pressure adopts the actual hydrostatic pressure, and the solid-liquid coupling mode is used to obtain the stress and displacement changes of the shaft surrounding rock. 


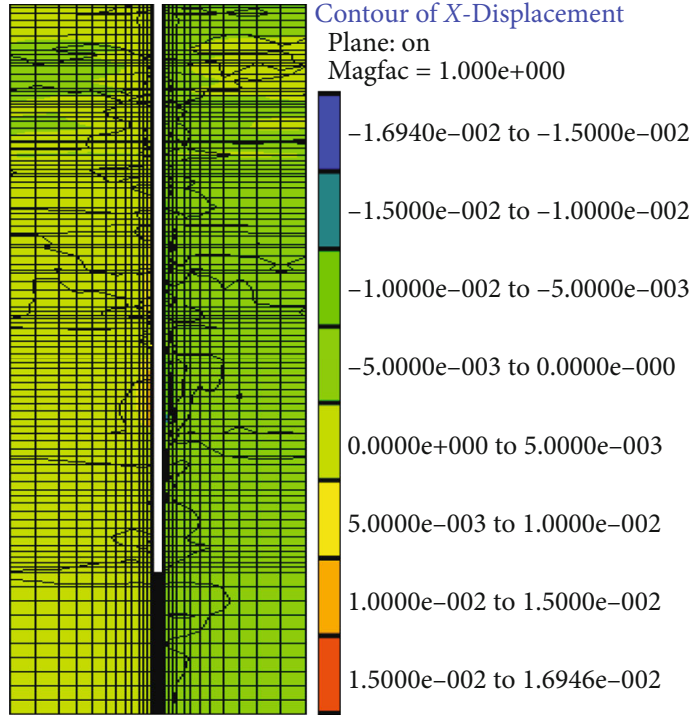

(a) Horizontal displacement

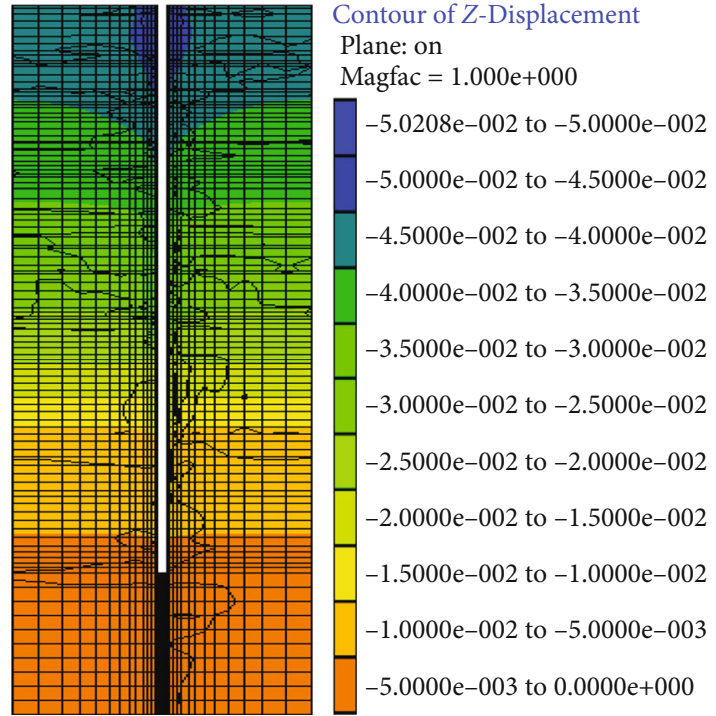

(b) Vertical displacement

FIGURE 22: Shaft surrounding rock displacement.

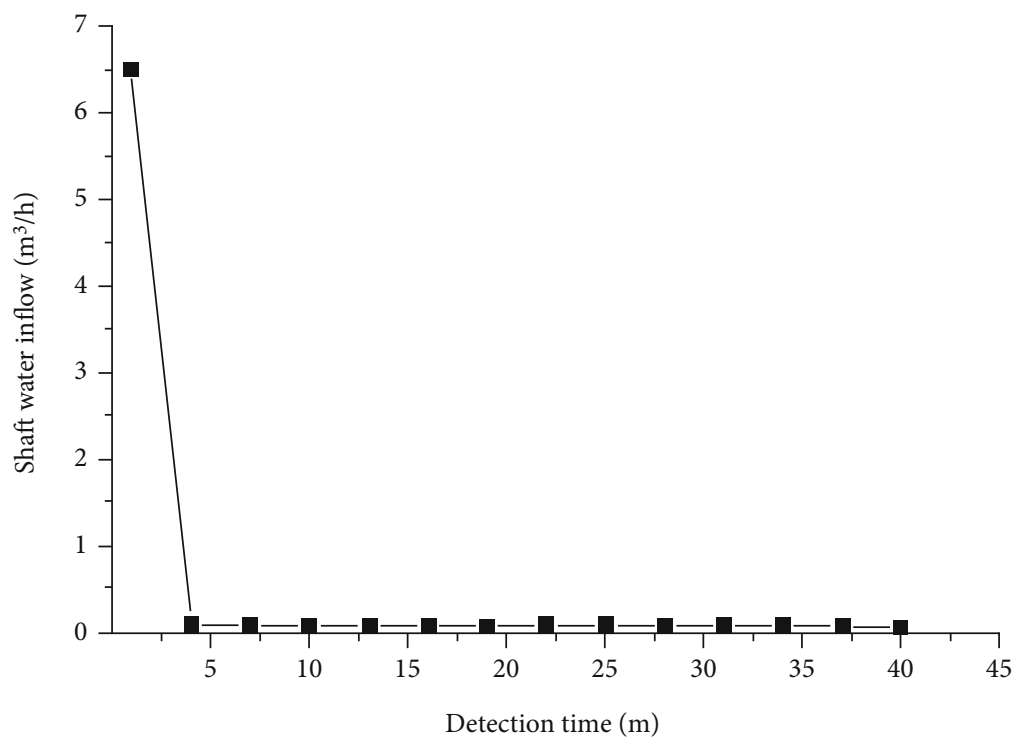

FIgURE 23: The measured water volume changes in the shaft.

It can be seen from Figure 21 that the stress change of the shaft surrounding rock has a nonlinear relationship with the depth, showing a wave-type state. The maximum tensile stress of the horizontal stress is $1.43 \mathrm{MPa}$, and the maximum compressive stress is $4.17 \mathrm{MPa}$. The stress of the surrounding rock after the grouting is less than the stress without grouting.

Figure 22 shows that after the water outlet point is grouted, the horizontal displacement of the shaft surrounding rock has a nonlinear relationship with the depth. The maximum horizontal displacement is $16.94 \mathrm{~mm}$, and the maximum vertical displacement is $50.21 \mathrm{~mm}$. Comparing Figures 15(b) and 16(b, it can be seen that the displacement of the shaft surrounding rock is smaller than the displacement without grouting.
6.4. Grouting Effect Analysis. When plugging the water outlet point of the topsoil, it is difficult to grout due to the annular cracks in the shaft surrounding rock. During the grouting process, a new water outlet point appears. At the same time, there is a cross-grout phenomenon within the water outlet area, and the smaller the water inflow, the more difficult to plug the water outlet point. Because of the above problems, it is necessary to increase the pump pressure and grouting volume to increase the spreading radius of the slurry, to reduce the new water outlet point. When plugging the water outlet point, the water plugging speed is slow, and it takes 10 30 minutes. The Malisan N grouting material is used to plug the five water outlet points in a short period; the shaft grouting takes 56 hours in total and consumes $3.20 \mathrm{t}$ of Malisan $\mathrm{N}$ raw material. After grouting, the measured water 
inflow is less than $0.05 \mathrm{~m}^{3} / \mathrm{h}$, and the shaft water inflow has not changed; the measured water volume changes in the shaft as shown in Figure 23.

\section{Conclusion}

(1) Through field data monitoring, the flow direction and velocity of the Quaternary water were $150^{\circ}$ $\left(\mathrm{ES} 60^{\circ}\right)$ and $0.73 \mathrm{~m} / \mathrm{h}$, respectively. At the same time, the characteristics of the rock mass around the main (auxiliary) shaft, the aquifer parameters (position, depth, thickness, and water inflow), and the hydraulic connection between the layers are obtained through flow monitoring

(2) Through the numerical simulation analysis of the groundwater seepage field, the change law of the shaft surrounding rock under the action of water bodies and the change rule of the groundwater seepage field around the shaft were obtained; the water outlet point was determined; and the grouting drilling parameters were optimized. Combined with experimental research, a grouting material based on Malisan $\mathrm{N}$ was selected and designed, and a self-locking oil seal technology was developed to improve the grouting efficiency

(3) The grouting behind the shaft linings was adopted to plug the water, which can effectively plug the water outlet point and reinforce the surrounding rock. The monitoring data show that there was no water spray in summer, the water inflow in winter has dropped to $0.05 \mathrm{~m}^{3} / \mathrm{h}$, and there is no change for a long time

\section{Data Availability}

The data used to support the findings of this study are included within the article.

\section{Conflicts of Interest}

The authors declare no conflicts of interest.

\section{Acknowledgments}

This study was funded by the National Natural Science Foundation of China (No. 51704152) and the Natural Science Foundation of Shandong Province (No. ZR2017PEE018, No. ZR2019BEE013, and No. ZR2017BEE001).

\section{References}

[1] G. Q. Zhou, H. C. Liang, and G. S. Zhao, "Test of grouting surrounding pile for improving bearing capacity," Journal of China University of Mining \& Technology, vol. 34, no. 3, pp. 265-269, 2005.

[2] Q. Yu, J. Ma, H. Shimada, and T. Sasaoka, "Influence of coal extraction operation on shaft lining stability in eastern Chinese coal mines," Geotechnical and Geological Engineering, vol. 32, no. 4, pp. 821-827, 2014.
[3] A. Mitelman, D. Elmo, and D. Stead, "Development of a spring analogue approach for the study of pillars and shafts," International Journal of Mining Science and Technology, vol. 28, no. 2, pp. 267-274, 2018.

[4] X.-b. Li, W. Zhang, D.-y. Li, and Q.-s. Wang, "Influence of underground water seepage flow on surrounding rock deformation of multi-arch tunnel," Journal of Central South University of Technology, vol. 15, no. 1, pp. 69-74, 2008.

[5] P. Roghanchi and K. C. Kocsis, "Quantifying the thermal damping effect in underground vertical shafts using the nonlinear autoregressive with external input (NARX) algorithm," International Journal of Mining Science and Technology, vol. 29, no. 2, pp. 255-262, 2019.

[6] Y. D. Jia, R. Stace, and A. Williams, "Numerical modelling of shaft lining stability at deep mine," Mining Technology, vol. 122, no. 1, pp. 8-19, 2013.

[7] C. C. Li, "Disturbance of mining operations to a deep underground workshop," Tunneling \& Underground Space Technology, vol. 21, no. 1, pp. 1-8, 2006.

[8] A. Jaiswal and B. K. Shrivastva, "Stability analysis of the proposed hybrid method of partial extraction for underground coal mining," International Journal of Rock Mechanics and Mining Sciences, vol. 52, pp. 103-111, 2012.

[9] Y.-Y. Yang, Y.-S. Xu, S.-L. Shen, Y. Yuan, and Z.-Y. Yin, "Mining-induced geo-hazards with environmental protection measures in Yunnan, China: an overview," Bulletin of Engineering Geology \& the Environment, vol. 74, no. 1, pp. 141-150, 2015.

[10] L. Tong, L. Leo, B. Amatya, and S. Liu, "Risk assessment and remediation strategies for highway construction in abandoned coal mine region: lessons learned from Xuzhou, China," Bulletin of Engineering Geology \& the Environment, vol. 75, no. 3, pp. 1045-1066, 2016.

[11] J. Konior, "Development of load exerted on the lining of the shaft after its liquidation / Kształtowanie Się Obciążeń Obudowy Szybu Po Jego Likwidacji," Archives of Mining Sciences, vol. 60, no. 1, pp. 253-263, 2015.

[12] F. S. Ma, Q. H. Deng, D. Cunningham, R. M. Yuan, and H. J. Zhao, "Vertical shaft collapse at the Jinchuan Nickel Mine, Gansu Province, China: analysis of contributing factors and causal mechanisms," Environmental Earth Sciences, vol. 69, no. 1, pp. 21-28, 2013.

[13] Y. Hang, G.-1. Zhang, and G.-y. Yang, "Numerical simulation of dewatering thick unconsolidated aquifers for safety of underground coal mining," Mining Science and Technology, vol. 19, no. 3, pp. 312-316, 2009.

[14] Y.-c. Xu, X.-d. Li, and Y.-x. Jie, "Test on water-level stabilization and prevention of mine-shaft failure by means of groundwater injection," Geotechnical Testing Journal, vol. 37, no. 2, pp. 20130027-20130332, 2014.

[15] Y. Xu, J. Li, Q. Zhang, and X. Wang, "Engineering parameters of water injection to control mine shaft damage at Jisan coal mine," Journal of Liaoning Technical University (Natural Science), vol. 33, no. 9, pp. 1153-1158, 2014.

[16] D. Lin and X. Wu, "Study on water blocking and reinforcing by grouting and anchoring method in a shaft about one kilometer," Chinese Journal of Rock Mechanics and Engineering, vol. 23, no. s1, pp. 4666-4668, 2004.

[17] G. Q. Zhou, Y. Z. Liu, X. W. Feng, and G. S. Zhao, “Application and effect of grouting in surrounding soil on releasing and restraining additional stress of shaft lining," Chinese Journal of Geotechnical Engineering, vol. 27, no. 7, pp. 3274-3280, 2004. 
[18] A. Aalianvari, "Optimum depth of grout curtain around pumped storage power cavern based on geological conditions," Bulletin of Engineering Geology and the Environment, vol. 73, no. 3, pp. 775-780, 2014.

[19] Y. S. Wang, Z. J. Yang, and W. H. Yang, "Viscoelastic analysis of interaction between freezing wall and outer shaft wall in freeze sinking," Procedia Earth and Planetary Science, vol. 1, no. 1, pp. 612-620, 2009.

[20] G. Walton and M. S. Diederichs, "A mine shaft case study on the accurate prediction of yield and displacements in stressed ground using lab-derived material properties," Tunneling \& Underground Space Technology, vol. 49, pp. 98-113, 2015.

[21] H. Ozturk and E. Guler, "A methodology for lining design of circular mine shafts in different rock masses," International Journal of Mining Science and Technology, vol. 26, no. 5, pp. 761-768, 2016.

[22] H. C. Liang, G. Q. Zhou, and Z. Q. Liu, "In-situ tests on ground surface settlement and additional strain of shaft linings," Chinese Journal of Geotechnical Engineering, vol. 32, no. 6, pp. 925-928, 2010.

[23] J. H. Huang and W. H. Yang, "Study on variation of vertical additional force on shaft lining by simulation tests," Chinese Journal of Geotechnical Engineering, vol. 28, no. 10, pp. 1205-1207, 2006.

[24] H. Cheng, J. Su, and Z. S. Yao, "Study on distributing rule of additional force of compressible shaft wall in hydrophobic settlement stratum," Rock and Soil Mechanics, vol. 28, no. 3, pp. 471-475, 2007.

[25] Y. Wang, C. Zhang, L. Xue, and X. Huang, "Prediction and safety analysis of additional vertical stress within a shaft wall in an extra-thick alluvium," Mining Science and Technology, vol. 20, no. 3, pp. 350-356, 2010.

[26] Z. Q. Meng, H. G. Ji, and F. Peng, "Additional stress of shafting linings in thick alluvium constructed by freeing process," Journal of China Coal Society, vol. 38, no. 2, pp. 205-208, 2013.

[27] H. C. Xia and M. A. Tang, "Mechanism and application of grouting into topsoil to prevent shaft lining from fracturing," Journal of Mining and Safety Engineering, vol. 26, no. 4, pp. 407-412, 2009.

[28] R. Yang, Q. Wang, and L. Yang, "Closed-form elastic solution for irregular frozen wall of inclined shaft considering the interaction with ground," International Journal of Rock Mechanics and Mining Sciences, vol. 100, pp. 62-72, 2017. 